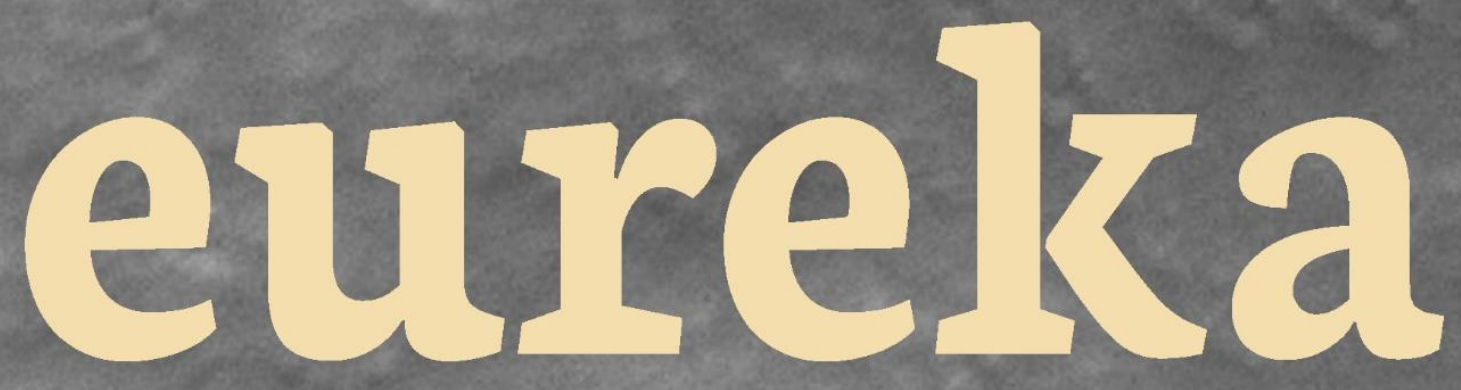

Undergraduate Science Journal

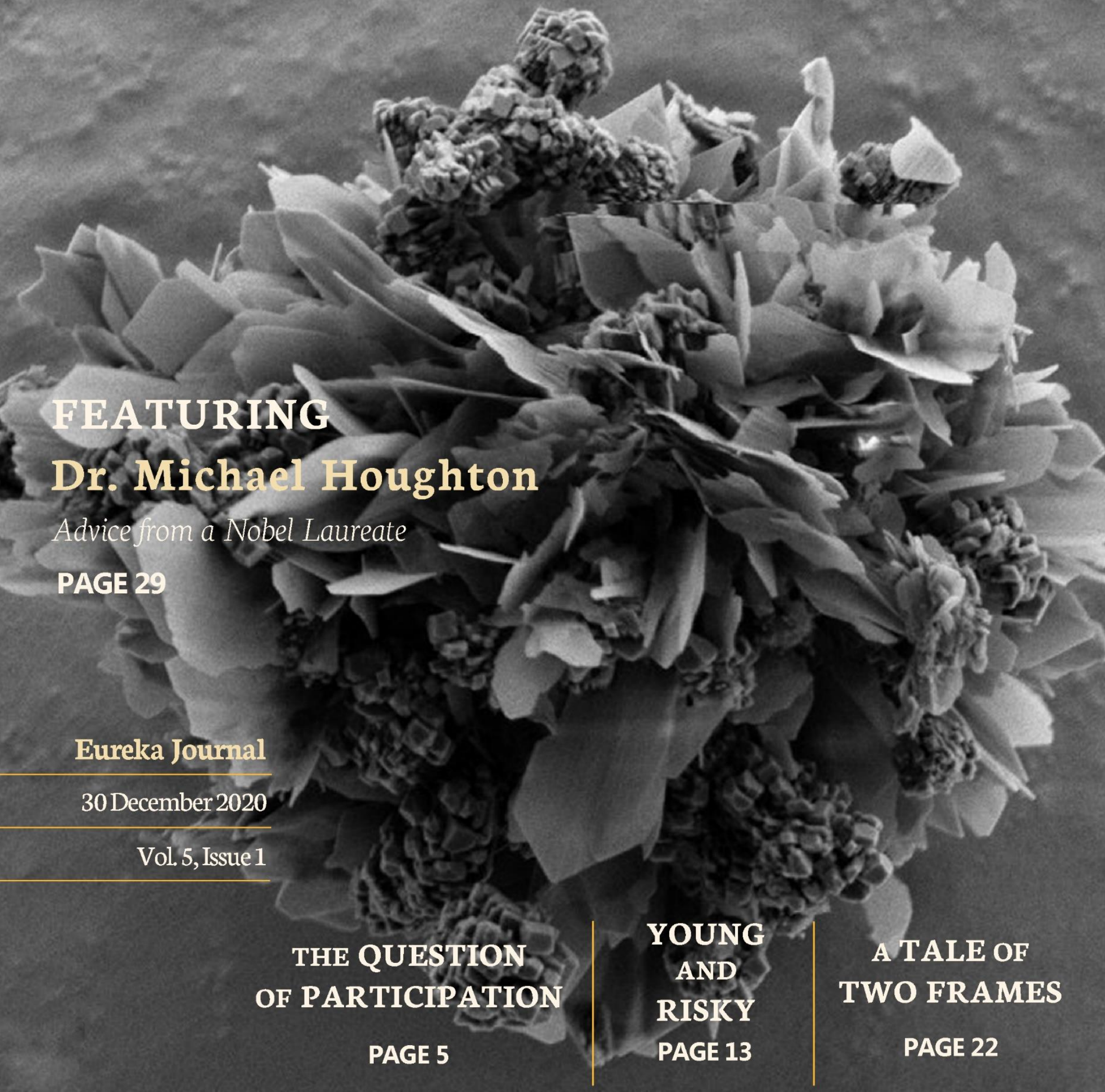


Eureka Undergraduate Science Journal published its first issue a decade ago in Winter 2010, publishing four full issues up to 2014. A decade later, and after 6 years of hiatus, we are proud to present a re-established journal and team. In this issue of Eureka, we hope to exemplify our mission to support quality peer-reviewed research by undergraduate scientists, as well as foster excitement for science in our community. 
Eureka is a student-founded and student-run initiative.

This journal offers

undergraduate scientists the unique opportunity to share their discoveries with the scientific world through the peer review process. Eureka is an educational institution,

with a diverse team of reviewers from many scientific backgrounds, exposing undergraduate students to the publication process often excluded from their traditional scientific education. Through clear and effective scientific writing, students will be able to work together with faculty members to contribute original research and promote science.

Our mission is to support and promote quality peer-reviewed research by undergraduate scientists.

\section{Contents}

From the Desk of Dr. Jennifer Passey. 1

Featured Research Images 3

Student Researcher Spotlight 4

The Question of Participation: An Investigation on Interventions to Increase Physical Activity Among University Students

Azmi, $A$. 5

\section{Young and Risky: Sexual Behaviours Among Generation $\mathrm{Z}$ and Millennials}

Dhanoa, A., Ehsan, F., Huxter, K., Moller, C.L., Nolet-Mulholland, L., Dahal, $R$.

\section{A Tale of Two Frames: A Study on the Effects of Framed Health Messages on Autonomous Motivation for Physical Activity}

Azmi, A., Cruz, C.B. 22

Featuring Michael Houghton

EDITORIAL TEAM

Mary Cheuk

Faculty of Science

Daniela Roth School of Dentistry

Sherry Gu

Faculty of Science Ludwig Paul Cabling Department of Civil and Environmental Engineering 


\section{From the desk of Dr. Jennifer Passey}

July 2019

As Faculty Advisor, it is my great pleasure to welcome you to the new edition of Eureka. I am excited that the Interdepartmental Science Students' Society (ISSS) is restarting this journal, and once again giving undergraduate students in Science the opportunity to publish their work. I think this journal supports student engagement in two important roles; those as research consumers and research producers (Morling, 2018).

Beth Morling, a professor of psychology at the University of Delaware, is the author of an innovative and engaging textbook on research methodology. Morling (2018) makes a distinction between the roles of research consumers and research producers. Undergraduate science students are research consumers; they learn and read about research to understand the topics, phenomena, and methodologies within their disciplines. For example, psychology students may learn about how autobiographical memory works, how we pay attention to social information, how cultural worldviews help people manage anxiety about death, or what neuroimaging tells us about the visual attention system. Undergraduate science students are also research producers. Through their coursework, labs, independent studies, honors theses, and other research opportunities, they frequently develop new research questions, and conduct their own investigations to answer those questions. For example, some psychology students engage in research investigating the socialization of cultural practices, or how decision-making changes as a function environment. Others many conduct research on the development of executive function in childhood, or how learning and cognitive abilities allow animals to solve problems they face in the wild.

Of course, there are connections between the consumer and producer roles: both share a desire for knowledge, and a faith in empiricism (Morling, 2018). In addition, when developing new research questions, hypotheses, and methodologies, research producers routinely review prior research to inform their own investigations.

Furthermore, participation in both of these roles fosters skill development that may be important for students' future careers (Morling, 2018). Regardless of career choice, everyone needs to be an intelligent consumer of information. Understanding research methods prepares students to evaluate critically any research information presented in the media related to new medical advances, diet and exercise, or parenting and relationship advice. Many students continue to consume research information for their own enjoyment, or perhaps with the goal of applying the information to their work or their personal lives. For example, many psychology students go on to obtain jobs as social workers, therapists, parole or corrections officers, teachers, entrepreneurs, market research analysts, or human resource specialists. People in these jobs are often required to complete critical evaluations of research evidence, and propose relevant policies or solutions to the problems they face in these roles. For instance, they may consume research on the effectiveness of experimental treatments on recovery following stroke for use with rehabilitation patients. Others may read research in child development to inform social policy in early learning and childcare, and others may investigate the role of communication in cross-cultural adaptation for developing supports for new immigrants to Canada.

Of course, many undergraduate science students pursue careers as research producers. For example, psychology students may envision future careers where they investigate the link between genetic and lifestyle factors on the development of dementia. Others may want to study how structures like the hippocampus are involved in the relation between sleep and long-term episodic memory. Others may want to delve deeper into the psychological processes of leadership, or research how conceptual knowledge affects the way people understand and use language. Conducting their own research as students teaches them how scientists ask

questions and think about their discipline (Morling, 2018). This experience helps to prepare them for academic jobs as professors, or work as scientists at other research institutions.

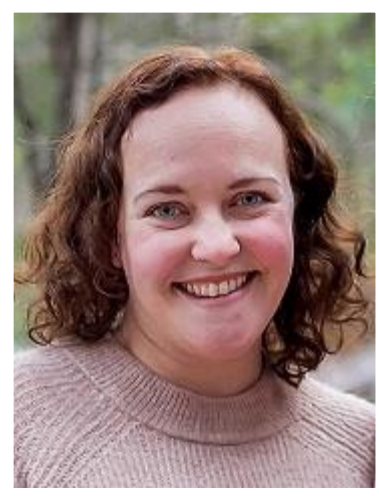


The Eureka journal facilitates participation in both the consumer and producer roles. This journal provides students the opportunity to publish and disseminate their work as research producers. In addition, it allows students as research consumers to become more familiar with work of other science students from other disciplines, with which they may not be familiar. Finally, the interdisciplinary nature of the journal may foster inspiration for new research ideas, as findings from one discipline may inform theory and help develop new hypotheses in another discipline.

As the new era of Eureka begins, I look forward to seeing a variety of interesting contributions from students across all of the science areas.

Jennifer Passey, Ph.D.

Teaching Professor, Department of Psychology

Eureka Faculty Advisor

\section{REFERENCES}

Morling, B. (2018). Research Methods in Psychology: Evaluating a World of Information (3rd Edition). New York, NY: W. W. Norton

\& Company, Inc. 


\title{
eurelka Featured Research Images
}

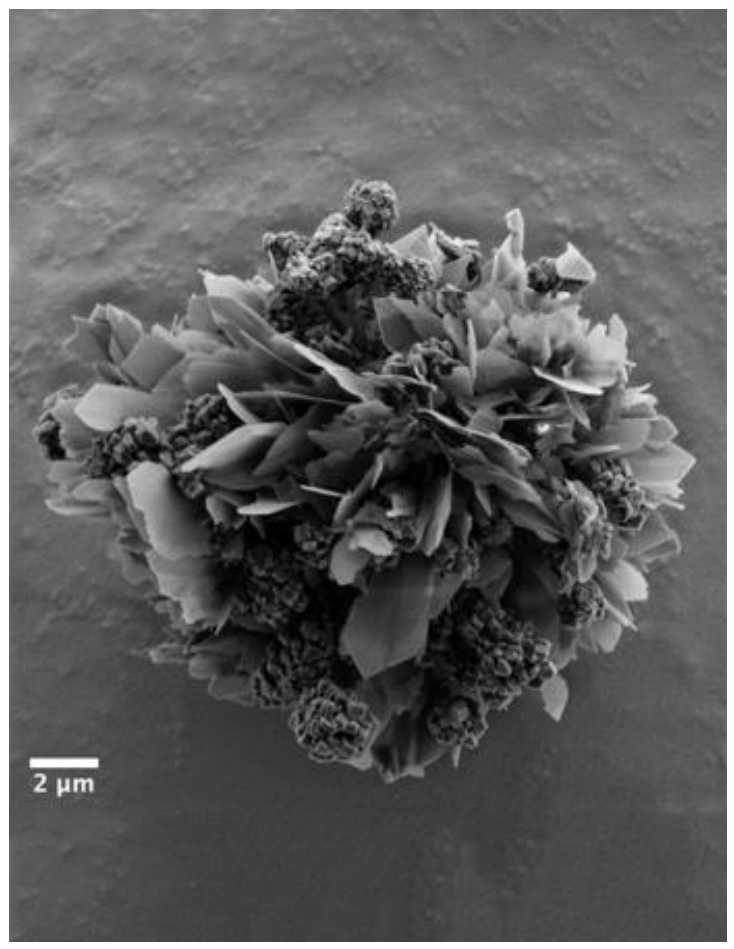

\section{Laboratory synthesized Mg- carbonates from the amorphous phase under high temperature}

\begin{abstract}
This image shows an assemblage of $\mathrm{Mg}$-carbonates in a microscale. The globular clustered minerals are magnesite, and the other ones with platy shapes are the hydrated form of magnesite - hydromagnesite. They crystallized from the same amorphous phase that was synthesized in the laboratory environment, and kept incubated at $75^{\circ} \mathrm{C}$. The image represents a tiny fraction of my year-long project, about probing the amorphous-tocrystalline transition in the Ca-Mg-carbonate system, as a function of composition, time, and temperature. The research did not only focus on the morphology perspective, but also quantitatively study the change in mineralogy over the entire time span.
\end{abstract}

Created by: Jie Cheng

$4^{\text {th }}$ Year, BSc Honors in Environmental Earth Sciences

\section{Tissue engineered human fibrocartilage}

Cartilage is a mechanically crucial connective tissue with subtypes including hyaline cartilage, fibrocartilage, and elastic cartilage. Hyaline cartilage provides joints with frictional properties that rival the finest engineering materials known to man Fibrocartilage has properties of both hyaline cartilage and fibrous tissue such as ligament. These allow it to transmit both tensile and compressive forces in structures such as the knee meniscus and the intervertebral disc of the spine while remaining soft and pliable. Elastic cartilage such as that of the ear are highly bendable.

Unfortunately, the evolution of cartilage's amazing properties came at a cost: it has no blood supply, which limits healing after injury. There are no known instances in nature where cartilage repairs itself to its original state in adults, not even in cartilaginous fish. Joint cartilage injuries lead to osteoarthritis, a painful and chronic joint disease with no existing cure.

You are looking at the cross-section of human meniscal fibrocartilage grown in just 3 weeks in the Adesida lab of the Department of Surgery, University of Alberta from nothing but human cells (blue) and a simple biomaterial scaffold made from bovine collagen. The cells came from a tiny piece of meniscus tissue from a 40-year-old man. Despite their adult origin, the cells regrew the main constituents of meniscal fibrocartilage under controlled conditions: human collagens I (red) and II (green). This technology may allow

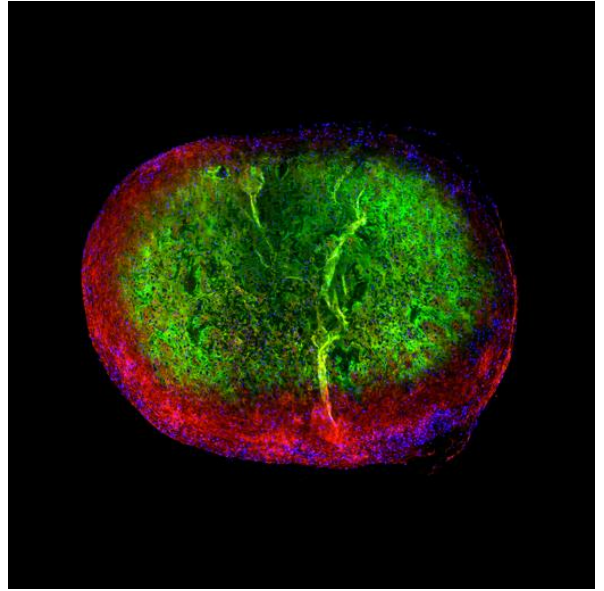

generation of meniscal fibrocartilage replacements using cells from a patient's damaged tissues, an innovation that could improve the lives of countless Canadians.

Created by:
David Li
and colleagues

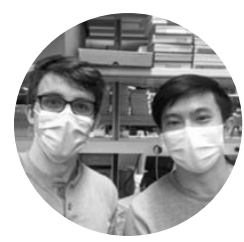


Jie Cheng is a student in the Faculty of Science, researching carbonates, environmental geochemistry, and carbon sequestration. Her image The laboratory synthesized Mg-carbonates from the amorphous phase under high temperature is featured on the front cover of this issue.

C6 I'm in my fourth year of Environmental Earth 66 Science. I was born and raised in Shanghai, China. Never thought of studying abroad when I was little. It did take me a lot of courage. But here I am, an international student at the U of A. When I'm not busy with school and research, I like to stay home, read books, and watch films. But personally, the best thing to do at home is baking!

\section{Other than this field, what is another discipline you see yourself working in?}

Maybe chemistry. I always have so much fun studying chemistry.

\section{What was your experience entering research?}

I actually got lucky. When I was reviewing for my Mineralogy final, I noticed on the second last slide of the last lecture that the professor was looking for a research assistant for her lab. I was kind of surprised when I first saw that slide, and I wasn't sure if I was qualified. But when I asked her about it later, she said "yes". Just for reference, my grade for that class was an A+, and maybe that matters.

Honestly, getting into research is not hard in the Department of Earth and Atmospheric Sciences. The undergraduate administrator let us know of research opportunities through emails, and some professors stuck a piece of paper on the door of the lab room to recruit student research assistants. So, my advice for students is:

\section{Actively look for the opportunities out there, instead of waiting for someone to hand it to you.}

\section{What inspires you in doing your research?}

I am inspired because I want to do something environmentalrelated. I became an environmentalist many years ago after watching a documentary criticizing the pollution problem. I plan to pursue a career in science. I'm not sure about the details yet, but it will definitely be about carbon sequestration or remediation of groundwater contamination.

\section{What do you think about the 'publish or perish' attitude in science?}

Well, I guess we have to treat this from two perspectives. There's no doubt that it puts pressure on us students and on almost every single person who wants to do well in research.

\section{Publications are the business cards of scientists.}

So, many of us aim to publish as much as possible. Because of that, some might prefer short-term studies instead of spending years and years focusing on a single research question, and validation tests are sometimes omitted. But another reason is probably because no results and no publications mean no funding. But sometimes, peer pressure and competition become motivation for working harder and being more selfregulating. Publications and impact factor are also a more quantitative way to assess and understand the ability of researchers.

\section{What was your favorite undergraduate lecture?}

My favorite lecture from Mineralogy on heterogeneous nucleation. Simply speaking, heterogeneous nucleation is the nucleation that happens on a surface rather than occurring randomly. In that lecture, the professor, my current supervisor, brought a petri dish into the class and asked somebody to scratch the plate-the volunteer made a tic-tac-toe grid. Then, she poured a solution into the plate. We thought the crystals would form the shape of the tic-tac-toe, but in reality, it did not! The petri dish is still in my current lab, and every time I wash it, I find it hilarious. Sorry if the story doesn't sound interesting, I'm bad at storytelling.

\section{What's one piece of advice that has stuck with you and you would give to other student researchers?}

Sort out the data and write your notes right after finishing the experiment. I tend to procrastinate a lot and always leave things to do later. Sometimes, the tasks accumulate and become overwhelming, and I end up having trouble remembering my earlier thoughts. 


\section{eurelka Research article}

\section{The Question of Participation: An Investigation on Interventions to Increase Physical Activity Among University Students}

Received: 27 July 2020

Accepted: 17 September 2020

Published: 30 December 2020

\author{
Aryan Azmi ${ }^{1 *}$ \\ ${ }^{1}$ School of Public Health, University of Alberta \\ *Corresponding author: aazmi@ualberta.ca
}

\section{ABSTRACT}

Background Recent studies indicate that physical activity levels among Ontario university students are about $35 \%$ to $42 \%$. Furthermore, there is a sparsity of evidence on effective interventions to support increased physical activity among university students. The current study uses the Comprehensive School Health (CSH) framework for the analysis of current physical activity interventions at York University and provides four observations of an effective program.

Methods 249 York University undergraduate students ( $\mathrm{n}=153$ women, $\mathrm{n}=96$ men) ages $18-42(\mathrm{M}=19.92$ years, $\mathrm{SD}=2.99$ for men; $\mathrm{M}=19.96$ years, $\mathrm{SD}=2.61$ for women) were recruited from the school of Kinesiology and Health Sciences. Participants were measured for their physical activity status and physical activity factors pertaining to the CSH framework via an online survey.

Results $67.9 \%$ of the participants were considered physically active, and 80.3\% declared they would not "travel to the university only to engage in physical activity". Additionally, $74.7 \%$ of the participants reported that they believed that they had enough information regarding physical activity, with $44.2 \%$ having been exposed to signs and posters about physical activity on campus. 49.4\% of participants reported engaging in the school's mandatory practicums (PKINs) with a resulting 125 minutes of average weekly physical activity. 16.9\% of participants reported having received physical activity counseling and $83.1 \%$ did not.

Conclusions Based on the results of this study, an effective intervention to support increased physical activity among university students, in the case of York University, was one that fit well with the students' academic schedule, did not rely on signs or posters for physical activity promotion, integrated itself into the curriculum, and would benefit from incorporating partnerships with healthcare professionals.

KEY WORDS: Comprehensive School Health Framework, Physical Activity Promotion, Health Promotion, Health Policy

\section{1 | INTRODUCTION}

A review of recent surveys on the physical activity levels of Ontario university students paints a dark picture of the state of physical activity amongst this population; two surveys conducted by the American College Health Association on more than 40,000 Ontario university students in 2013 and 2016 puts the physical activity rate of this group at $38 \%$ and $42 \%$, respectively. These rates are further corroborated by a 2007 study by Irwin; in this study, 392 undergraduate students from two universities in southwestern Ontario were surveyed and it was revealed that only $35 \%$ were physically active. In addition, a similar rate of physical activity (35\%) has been reported for students at York University (College Health Association, 2013).
What makes the implications of these results more troubling is the operational definition used by these studies to determine physical activity status; in all four studies, students were

considered physically active if they had engaged in a combination of moderate physical activity for at least 30 minutes on 5 or more days per week, or vigorous physical activity for at least 20 minutes on 3 or more days per week. This categorization sees an individual who engages in 60 minutes ( $3^{\star} 20$ minutes) of vigorous physical activity per week as "physically active". This contrasts with the definition put forth by the Canadian Society for Exercise Physiology (CSEP). CSEP states that "adults aged 18-64 years should accumulate at least 
150 minutes of moderate to vigorous-intensity aerobic physical activity per week" (CSEP, 2017).

Using the CSEP definition, it is reasonable to assume that the physical activity rates of university students in Ontario are likely lower than those measured by the studies.

It is unfortunate that so few university students are physically active in their day-to-day lives, given the numerous benefits of physical activity. Students stand to gain much from an increase in their physical activity levels as there are many benefits to physical activity. Physical activity has been shown to decrease the risk of coronary heart disease (Paffenbarger, Hyde, Wing, \& Hsieh, 1986; Morris \& Froelicher, 1991; Chandrashekhar \& Anand, 1991; Smith et al., 1995), modulate the risk factors related to the occurrence of type 2 diabetes (Uusitupa et al, 2000), reduce the negative effects of obesity (He \& Baker, 2004), lower the incidence of hypertension (Paffenbarger, Wing, Hyde, \& Jung, 1983), increase the health-related quality of life in survivors of cancer (Blanchard et al., 2004; Penedo, Schneiderman, \& Dahn, 2004), enhance functionality in patients with osteoarthritis (Lin, Davey, \& Cochrane, 2004), diminish symptoms of depression and anxiety (Ross C \& Hayes, 1988; Stephens, 1988), and even lower the risk of erectile dysfunction in men (Derby et al., 2000).

A physical activity intervention is an intervention designed to improve physical activity levels within any population; it is therefore pertinent to review interventions that have been attempted in the past. Unfortunately, lack of effect within physical activity interventions is common. In a 1998 review by Baranowski, Anderson, \& Carmack, it has been pointed out that a majority of physical activity intervention studies have shown little to no effect. Furthermore, those interventions that have been shown to have statistically significant results demonstrated minute effect sizes. These findings were repeated in our review of physical activity intervention studies published from 2000 - 2012 which targeted university students; a lack of long-term effects was observed across interventions targeting university students (Table 1). This lack of results is despite the fact that students are shown to place great importance on their physical activity (Wilson, Rodgers, Fraser, \& Murray, 2004).

Since most current and past interventions have proven to be unsuccessful, a new perspective was used in order to organize this study: the Comprehensive School Health (CSH) framework. This framework has been endorsed by the World Health Organization as an effective tool for health promotion within schools and universities (2006). The CSH posits that successful interventions benefit from targeting the following four interrelated pillars:

- Social and Physical Environment. the "quality of relationships, and emotional well-being of students and staff, in addition to the buildings, grounds, spaces around the school, and essential requirements such as air and water quality." (Bassett-Gunter, Yessis, Manske, \& Stockton, 2012)

- Teaching and Learning: provision of formal and informal education opportunities to support the development of the skills required to engage in physical activity and improve mental health and well-being.

- Healthy School Policy. management practices, rules, procedures and policies that support the promotion of physical activity and promote mental health and well-being.

- Partnerships and Services. health, education and other sectors working together to support the promotion of physical activity and mental health; community and school-based services that support and promote physical activity and mental health (Bassett-Gunter, Yessis, Manske, \& Stockton, 2012).

The purpose of this study is to explore potential factors categorized based on the pillars put forth by the CSH that can influence the effectiveness of interventions to support increased physical activity rates among university students.

\section{2 | METHODS}

Study Design: an online survey was utilized for this descriptive study.

Participants: York University undergraduate students ( $\mathrm{N}=249$; $\mathrm{n}=153$ women, $\mathrm{n}=96 \mathrm{men})$ ages $18-42(\mathrm{M}=19.92$ years, $\mathrm{SD}=$ 2.99 for men; $\mathrm{M}=19.96$ years, $\mathrm{SD}=2.61$ for women) were recruited through an online portal: Kinesiology Undergraduate Research Experience (KURE). KURE is a research portal that allows undergraduate kinesiology students from York University to enroll in available studies. These 249 students were given bonus marks in a course that was not taught by any of the researchers in this study, as a token of appreciation for their participation.

Protocol: an online survey was conducted using SurveyMonkey. An initial email was sent to all the participants through the KURE system providing them with a link to the study. One to two reminders were sent to participants who were unresponsive to the initial email. Within the survey, participants were given information about the study and were asked for their written consent. 
Table 1. Interventions targeting physical activity among university students

\begin{tabular}{|c|c|c|c|c|c|c|c|}
\hline Author(s) & Year & Participants & Description of the Intervention & $\begin{array}{c}\text { Posttest Results Regarding Physical } \\
\text { Activity Rate }\end{array}$ & $\begin{array}{l}\text { Follow-up } \\
\text { Performed }\end{array}$ & $\begin{array}{l}\text { Time of } \\
\text { Follow-up }\end{array}$ & Follow-up Results \\
\hline Saelens et al. & 2000 & $\begin{array}{l}256 \text { students from one } \\
\text { university in southern } \\
\text { California }\end{array}$ & $\begin{array}{l}\text { Phase one: Lectures } \\
\text { regarding physical activity benefits } \\
\text { Phase two: Phone and mail reminders and development of } \\
\text { behavioral and cognitive strategies }\end{array}$ & $\begin{array}{l}\text { A significant Increase in the } \\
\text { intervention group compared to } \\
\text { control }\end{array}$ & Yes & $\begin{array}{l}1 \text { and } 2 \text { years } \\
\text { following the } \\
\text { end of phase } \\
\text { two }\end{array}$ & $\begin{array}{l}\text { No significant difference } \\
\text { compared to control at 1- } \\
\text { or 2-years follow-up }\end{array}$ \\
\hline $\begin{array}{l}\text { Leslie, } \\
\text { Sparling, \& } \\
\text { Owen }\end{array}$ & 2001 & $\begin{array}{l}338 \text { students from one } \\
\text { university in the USA }\end{array}$ & $\begin{array}{l}\text { This intervention [Project GRAD] consisted of weekly lectures } \\
\text { and peer-led laboratory sessions. In this program, students were } \\
\text { asked to come up with a plan to engage in physical activity and } \\
\text { to increase and maintain activity in their lifestyle. }\end{array}$ & $\begin{array}{l}\text { No significant difference compared } \\
\text { to baseline for men. } \\
\text { A significant increase compared to } \\
\text { baseline in women. }\end{array}$ & Yes & $\begin{array}{l}2 \text { years } \\
\text { following the } \\
\text { end the study }\end{array}$ & $\begin{array}{l}\text { No significant difference } \\
\text { compared to baseline at 2- } \\
\text { years follow-up. }\end{array}$ \\
\hline
\end{tabular}

\begin{tabular}{|c|c|c|c|c|c|c|c|}
\hline $\begin{array}{l}\text { Cholewa \& } \\
\text { Irwin }\end{array}$ & 2008 & $\begin{array}{l}51 \text { students from University of } \\
\text { Western Ontario }\end{array}$ & $\begin{array}{l}\text { This intervention included two parts: } \\
\text { 1) Participants were divided into groups of two [of same-sex } \\
\text { participants] who worked together to increase their physical } \\
\text { activity. } \\
\text { 2) Students were asked to track their "activity frequency, } \\
\text { duration, goals, and progress." }\end{array}$ & $\begin{array}{l}\text { No significant difference compared } \\
\text { to baseline. }\end{array}$ & & \multicolumn{2}{|c|}{ No follow-up was performed } \\
\hline Franko et al. & 2008 & $\begin{array}{l}476 \text { students from six } \\
\text { universities across the USA }\end{array}$ & $\begin{array}{l}\text { Online module regarding nutrition and physical activity. This } \\
\text { information was tailored specifically for university students }\end{array}$ & $\begin{array}{l}\text { No significant difference compared } \\
\text { to control }\end{array}$ & Yes & $\begin{array}{l}3 \text { and } 6 \text { months } \\
\text { following the } \\
\text { end the study }\end{array}$ & $\begin{array}{l}\text { No significant difference } \\
\text { compared to control at 3- } \\
\text { or 6-months follow-up }\end{array}$ \\
\hline
\end{tabular}

\begin{tabular}{|c|c|c|c|c|c|c|}
\hline $\begin{array}{l}\text { Boyle, } \\
\text { Mattern, } \\
\text { Lassiter, } \\
\text { Ritzler }\end{array}$ & $\&$ & 2011 & $\begin{array}{l}178 \text { students from one } \\
\text { university in the USA }\end{array}$ & $\begin{array}{l}\text { This intervention consisted of two parts: } \\
\text { 1) Students received a lecture on behavior change, goal setting, } \\
\text { planning for change, and rewards. } \\
\text { 2) Students had to choose one of two semester-long behavior } \\
\text { change projects as part of their academic course: } \\
\text { I) "Attempt to change a behavior of the student's choice } \\
\text { without outside help (control)." } \\
\text { II) "Attempt to improve the student's level of PA and physical } \\
\text { fitness with the help of an exercise physiologist in training } \\
\text { (intervention)." }\end{array}$ & $\begin{array}{l}\text { No significant difference compared } \\
\text { to control for men. } \\
\text { A significant increase compared to } \\
\text { control in women. }\end{array}$ & No follow-up was performed \\
\hline $\begin{array}{l}\text { Magoc, } \\
\text { Tomaka, } \\
\text { Bridges- } \\
\text { Arzaga } \\
\end{array}$ & $\&$ & 2011 & $\begin{array}{l}117 \text { students from one } \\
\text { university in southwestern USA }\end{array}$ & $\begin{array}{l}\text { Online lessons regarding physical activity, self-regulation } \\
\text { skills, goal setting, self-efficacy, barriers, social support, and } \\
\text { outcome expectations and expectancies }\end{array}$ & $\begin{array}{l}\text { A significant increase compared to } \\
\text { control }\end{array}$ & No follow-up was performed \\
\hline Cavallo & & 2012 & $\begin{array}{l}134 \text { female undergraduate } \\
\text { students from one university in } \\
\text { southeastern USA }\end{array}$ & $\begin{array}{l}\text { A Facebook group was created and participants [all female] } \\
\text { were invited to join. The group was meant to provide social } \\
\text { support and facilitate the exchange of physical activity-related } \\
\text { information. }\end{array}$ & $\begin{array}{l}\text { No significant difference compared } \\
\text { to control. }\end{array}$ & No follow-up was performed \\
\hline
\end{tabular}


After they consented to take part in the study, the respondents were asked to indicate their sex, an estimate of their weekly physical activity (in minutes), then were directed to a questionnaire regarding factors that affected their physical activity. The questions were presented in a random order for each participant in order to minimize carryover effects (Tourangeau, Rasinski, Bradburn, 1989). The participants were granted their marks upon the completion of the survey. The participants remained completely anonymous during the course of this survey.

This study was reviewed and approved by the Kinesiology and Health Science Delegated Ethics Review Committee, York University, and conforms to the standards of York University's Office of Research Ethics (REB\# 2017-18-XX).

Physical activity status : Participants were considered "physically active" if they engaged in more than 150 minutes of weekly physical activity, with physical activity being defined as any moderate to vigorous intensity bodily movement that requires energy expenditure. The 150 minute cut-off was taken from the Canadian Physical Activity Guidelines for Adults 18-64 years (2011).

Physical activity factors: Factors that affect students' physical activity were based on the pillars of the CSH. Unfortunately, established variables and questionnaires for this framework were unavailable. This is due to the fact that the CSH framework is still in its infancy (Bassett-Gunter, Yessis, Manske, \& Stockton, 2012). As such, unique items were generated to address CSH intervention factors. These items were constructed in a manner that would touch upon each pillar of the CSH: Social and Physical Environment, Teaching and Learning, Healthy School Policy, Partnerships and Services.

Physical activity factor - Social and Physical Environment: Within this pillar, two items were measured: students' willingness to travel to campus only to engage in physical activity, and average travel time to campus.

Physical activity factor - Teaching and Learning : Two items were measured regarding this pillar: students' awareness of relevant physical activity material ("how to optimize benefits, how often or how long to be active, how to avoid injury, etc."), and their exposure to material promoting physical activity within the campus.

Physical activity factor - Healthy School Policy: for this pillar, Three of York University's physical activity related policies were selected: PKINs (Practicum Kinesiology Classes), York
University Recreation App, and Drop-In classes at Tait McKenzie Centre and students' participation within them were measured.

Physical activity factor - Partnerships and Services: Apropos this pillar, students' current participation and willingness to engage in future fitness counseling was measured. Fitness counseling is broadly defined as an activity in which a health professional designs a physical activity plan for another individual in order to improve their health and wellbeing.

Statistical Analysis : Several custom frequency tables were built using IBM SPSS (version 24.0):

A) One where the rows were set to participants' sex and the columns to their physical activity status. This table was built in order to demonstrate the distribution of participants' physical activity status between the sexes.

B) One where the rows were set to participants' knowledge of physical activity and the columns to their exposure to material pertaining to physical activity. This table was built in order to demonstrate the distribution of participants' physical activity knowledge among those exposed to physical activity material and those who were not.

C) Furthermore, an independent-samples t-test was performed, comparing the average travel time to campus of those who indicated that they would travel to campus only to participate in physical activity, with those who indicated that they would not

\section{3 | RESULTS}

Physical activity status : 67.9\% of the participants were considered physically active. This rate was further broken down based on participants' sex with $75.0 \%$ of males and $63.4 \%$ of females being considered physically active (Table 2).

Table 2. Physical activity status of the participants broken down by sex

\begin{tabular}{ccccc} 
& & \multicolumn{3}{c}{$\begin{array}{c}\text { Physical Activity Status } \\
\text { (frequency) }\end{array}$} \\
\cline { 2 - 5 } & & Active & Inactive & All \\
\hline & Male & 72 & 24 & 96 \\
\cline { 2 - 5 } & Female & 97 & 56 & 153 \\
\cline { 2 - 5 } & All & 169 & 80 & 249 \\
\hline
\end{tabular}


Physical activity factor - Social and Physical Environment : 80.3\% of participants indicated that they would not "travel to the university only to engage in physical activity". There exists a significant difference between average commuting time for those who indicated that they would attend as opposed to those who would not attend $(\mathrm{p}=$.000397) (Table 3$)$.

Table 3. Average travel time of participants broken down by willingness to travel to campus

\begin{tabular}{ccccc}
\cline { 2 - 5 } & & \multicolumn{3}{c}{ Time to Campus (minutes) } \\
\cline { 2 - 5 } & & Mean & Frequency & STD \\
\hline & No & 54.2 & 193 & 28.5 \\
\cline { 2 - 5 } \\
\cline { 2 - 5 } \\
\cline { 2 - 5 }
\end{tabular}

Physical activity factor - Teaching and Learning: 74.7\% of the participants reported that they believed that they had enough information regarding physical activity. This is while only $44.2 \%$ of the participants reported having been exposed to signs and posters about physical activity on campus.

Physical activity factor - Healthy School Policy. $49.4 \%$ of participants reported engaging in PKINs with a resulting 125 minutes of average weekly physical activity, for those involved. Only 28.1\% of participants reported having made use of the York University Campus Recreation mobile app. In addition, $12.4 \%$ of participants reported partaking in drop-in classes offered at York University (Table 4).

Table 4. Frequency of participants involved with York University's policies

\begin{tabular}{|c|c|c|c|}
\hline & & \multicolumn{2}{|c|}{$\begin{array}{l}\text { Participants involvec } \\
\text { (frequency) }\end{array}$} \\
\hline & & Yes & No \\
\hline \multirow{3}{*}{$\frac{\grave{2}}{\frac{2}{0}}$} & PKINs & 123 & 126 \\
\hline & $\begin{array}{c}\text { York University Campus } \\
\text { Recreation mobile app }\end{array}$ & 70 & 179 \\
\hline & $\begin{array}{c}\text { Drop-in classes at York } \\
\text { University }\end{array}$ & 31 & 218 \\
\hline
\end{tabular}

Physical activity factor - Partnerships and Services. 16.9\% of participants reported having received physical activity counseling in the past 2 months. Of the 83.1\% that did not receive physical activity counseling, $67.6 \%$ reported that they would use these services if they were offered on campus (Figure $1)$.

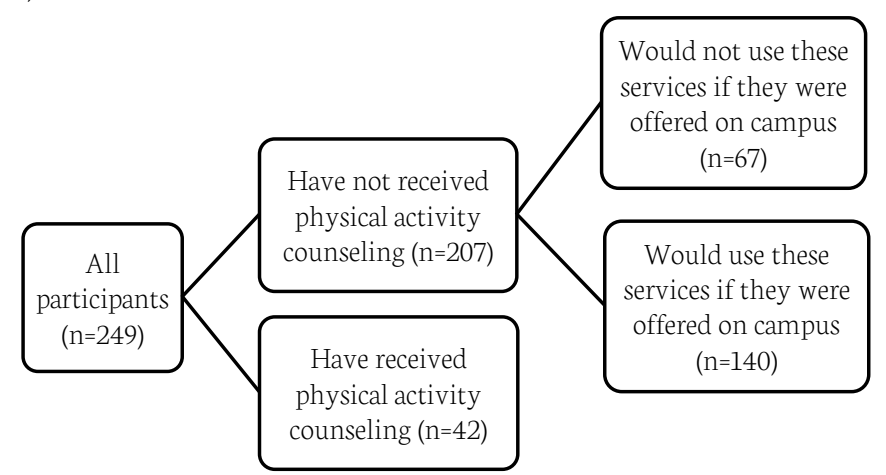

Figure 1. Chart of participants' utilization and willingness to use physical activity counseling

\section{4 | DISCUSSION}

Earlier studies have demonstrated that reduced participation in physical activity corresponds to increased barriers to physical activity (Epstein et al., 1991, 1995, 1997). However, the majority of research around physical activity promotion has focused solely on changing individual behaviors as a means to improve physical activity outcomes (Dishman, 1994). The findings of this study, on the other hand, draw upon the holistic CSH framework.

Regarding the results for the 'Physical activity factor - Social and Physical Environment', the students' willingness to travel to the school to engage in physical activity programming may be related to the students' commuting times. This is based on the observation that the students who were willing to travel to campus had shorter commutes, as opposed to those who were unwilling. This observation is consistent with a similar 2010 finding by Cerin, Leslie, Sugiyama, \& Owen. In their study, the commuting distance to a sports facility was, similarly, a deciding factor for the participants involved.

With respect to 'Physical activity factor - Teaching and Learning, most participants in this study reported that they had enough knowledge about physical activity. This is inconsistent with an earlier meta-analysis that, amongst other things, analyzed various articles regarding participants' knowledge of physical activity (de Melo Ghisi, Abdallah, Grace, Thomas, \& Oh, 2014). Based on the meta-analysis, average participants are considerably less informed about physical activity than the participants of this study. 
This inconsistency can be explained by the fact that the participants of this study were recruited from the Kinesiology and Health Sciences program at the university: a program that teaches its students about physical activity as a matter of curriculum.

Further regarding Physical activity factor - Teaching and Learning', the number of participants in this study who were aware of the health promotional material posted on campus is considerably lower than previous studies that utilized posters as their promotional material. In a 2001 study by Kerr, Eves, \& Carroll, 93\% of participants were aware of the promotional posters, and in a 1994 study by Ward and Hawthorne, 79\% of participants read the posters. It is likely that the lower awareness of the promotional material in the participants of this study is due to the environmental differences between these studies. The other studies took place in smaller, more enclosed physical environments, whereas this study took place in a vast campus where participants had a lower likelihood of encountering promotional material.

Apropos of 'Physical activity factor - Healthy School Policy', the results of this study show that more participants benefit from the school's mandatory practicums (PKINs) than the optional drop-in classes and the recreation mobile app. The integration of physical activity as part of the school curriculum for the purposes of physical activity promotion has been previously investigated; Physical Activity across the Curriculum (PAAC) was a three-year school-based intervention that demonstrated the effectiveness of using curriculum-based physical activity for the purposes of health promotion (Gibson et al., 2008, Donnelly et al., 2009).

With regards to 'Physical activity factor - Partnerships and Services', the results of this study show that even though the majority of participants had not received any form of health counselling, most would like to receive it. This is encouraging as previous research has shown that health counselling provided by health professionals have had a positive impact on the participants' physical activity levels (Calfas et al., 1996).

\section{Limitations of the Study}

The main limitations of this study pertain to its sample; the participants for this study were all recruited from a kinesiology course. These students are therefore not representative of the broader York University community as they are mostly within the kinesiology program, and students within the kinesiology program are exposed to much more information regarding exercise than any other program within the university. Furthermore, selection bias may affect this sample as well; students that choose a kinesiology degree may have different predisposition towards physical activity compared to students from other majors. A second limitation to this study, again apropos the sample, is the fact that this study gathers participants from one university only: York University. York University is a large school with 50,000 students, most of whom commute to school every day, which may not be the case for most universities. These factors bring the generalizability of the results into question.

\section{5 | CONCLUSIONS}

The findings of this study can be summarized into four observations for the construction of an intervention suited specifically to support increased physical activity rates among university students. It appears that a well-received intervention has the following characteristics:

1. Fits well with the students' academic schedule, as the majority of students will not travel to school only to engage in physical activity.

2. Does not rely on signs or posters for physical activity promotion and takes a different approach to the design and placement of promotional material, as many students tend to remain unaware of them.

3. Integrates itself into the curriculum (similar to the PKIN policy at York University), as this will engage students in nearly all their required weekly physical activity.

4. Incorporates partnerships with other organizations and offer services such as physical activity counseling to the students at the school, as most students have not received such a service, but would participate should it become available to them.

\section{Suggestions for Further Research}

The culminating evidence that was available regarding physical activity interventions for university students is sparse and has many weaknesses. None of the studies that were looked at for the purposes of this article have been replicated, they all have small sample sizes and some do not include a follow-up (Saelens et al., 2000, Leslie, Sparling, \& Owen, 2001, Cholewa \& Irwin, 2008, Franko et al., 2008, Boyle, Mattern, Lassiter, \& Ritzler, 2011, Magoc, Tomaka, \& Bridges-Arzaga, 2011, Cavallo, 2012). These factors must be addressed in future research to procure more reliable results. The lack of uniformity with regards to the definition of 'physical activity' throughout the available research is also a challenge. The studies cited in this paper have used diverging operational definitions for physical activity. This disunity creates a great impediment to the analysis and comparison of data across various studies. The introduction and use of a universal definition of physical activity would be of value. 
These factors must be addressed in future research in order to procure more reliable results. Finally, the independent testing of the efficacy of each of the four aforementioned observations and the testing of the observations as a whole could provide invaluable insight into whether the CSH framework is a viable alternative to the traditional approaches apropos of physical activity intervention to enhance participation levels within university students.

\section{ACKNOWLEDGEMENTS}

The author would like to thank Dr. Bassett-Gunter for her exceptional support of this project. Furthermore, the author thanks the School of Kinesiology and Health Sciences at York University for their logistical support during this study.

\section{REFERENCES}

American College Health Association. (2013). American College Health Association-National College Health Assessment II: York University Institutional Data Report Spring 2013. Hanover, MD: American College Health Association.

American College Health Association. (2013). American College Health Association-National College Health Assessment II: Ontario Province Reference Group Executive Summary Spring 2013. Hanover, MD: American College Health Association.

American College Health Association. (2016). American College Health Association-National College Health Assessment II: Ontario Canada Reference Group Executive Summary Spring 2016. Linthicum, MD: American College Health Association.

Baranowski, T., Anderson, C., \& Carmack, C. (1998). Mediating variable framework in physical activity interventions: How are we doing? How might we do better?. American journal of preventive medicine, 15(4), 266297.

Bassett-Gunter, R, Yessis, J, \& Manske, S, Stockton, L. (2012). Healthy School Communities Concept Paper. Ottawa, Ontario: Physical and Health Education Canada. Available at: http://www.phecanada.ca/programs/health-promotingschools/concept-paper

Blanchard, C. M., Stein, K. D., Baker, F., Dent, M. F., Denniston, M. M., Courneya, K. S., \& Nehl, E. (2004). Association between current lifestyle behaviors and health-related quality of life in breast, colorectal, and prostate cancer survivors. Psychology \& Health, 19(1), 1-13.
Boyle, J., Mattern, C. O., Lassiter, J. W., \& Ritzler, J. A. (2011). Peer 2 peer: efficacy of a course-based peer education intervention to increase physical activity among college students. Journal of American College Health, 59(6), 519-529.

Calfas, K. J., Long, B. J., Sallis, J. F., Wooten, W. J., Pratt, M., \& Patrick, K. (1996). A controlled trial of physician counseling to promote the adoption of physical activity. Preventive medicine, 25(3), 225-233.

Canadian Society for Exercise Physiology. (2017). Canadian Physical Activity Guidelines. Ottawa, ON: CSEP.

Cavallo, D. N. (2012). Using online social network technology to increase social support for physical activity: The Internet Support for Healthy Associations Promoting Exercise (INSHAPE) study (Doctoral dissertation, The University of North Carolina at Chapel Hill).

Cerin, E., Leslie, E., Sugiyama, T., \& Owen, N. (2010). Perceived barriers to leisure-time physical activity in adults: an ecological perspective. Journal of physical activity and health, 7(4), 451-459.

Chandrashekhar, Y., \& Anand, I. S. (1991). Exercise as a coronary protective factor. American Heart Journal, 122(6), 1723-1739.

Cholewa, S., \& Irwin, J. D. (2008). Project IMPACT: Brief report on a pilot programme promoting physical activity among university students. Journal of health psychology, 13(8), 1207-1212.

de Melo Ghisi, G. L., Abdallah, F., Grace, S. L., Thomas, S., \& Oh, P. (2014). A systematic review of patient education in cardiac patients: do they increase knowledge and promote health behavior change?. Patient education and counseling, 95(2), 160-174.

Derby, C. A., Mohr, B. A., Goldstein, I., Feldman, H. A., Johannes, C. B., \& McKinlay, J. B. (2000). Modifiable risk factors and erectile dysfunction: can lifestyle changes modify risk?. Urology, 56(2), 302-306.

Dishman, R. K. (Ed.). (1994). Advances in exercise adherence. Champaign, IL: Human Kinetics.

Donnelly, J. E., Greene, J. L., Gibson, C. A., Smith, B. K., Washburn, R. A., Sullivan, D. K., ... \& Jacobsen, D. J. (2009). Physical Activity Across the Curriculum (PAAC): a randomized controlled trial to promote physical activity and diminish overweight and obesity in elementary school children. Preventive medicine, 49(4), 336-341.

Epstein, L. H., Saelens, B. E., Myers, M. D., \& Vito, D. (1997). Effects of decreasing sedentary behaviors on activity choice in obese children. Health Psychology, 16, 107113. Decreases in sedentary behavior for obese children. International Journal of Behavioral Medicine, 2, 41-50. 
Epstein, L. H., Saelens, B. E., \& O’Brien, J. G. (1995). Effects of reinforcing increases in active behavior versus

Epstein, L. H., Smith, J. A., Vara, L. S., \& Rodefer, J. S. (1991). Behavioral economic analysis of activity choice in obese children. Health Psychology, 10, 311-316.

Franko, D. L., Cousineau, T. M., Trant, M., Green, T. C., Rancourt, D., Thompson, D., ... \& Ciccazzo, M. (2008). Motivation, self-efficacy, physical activity and nutrition in college students: Randomized controlled trial of an internet-based education program. Preventive medicine, 47(4), 369-377.

Gibson, C. A., Smith, B. K., DuBose, K. D., Greene, J. L., Bailey, B. W., Williams, S. L., ... \& Mayo, M. S. (2008). Physical activity across the curriculum: year one process evaluation results. International Journal of Behavioral Nutrition and Physical Activity, 5(1), 36.

He, X. Z., \& Baker, D. W. (2004). Body mass index, physical activity, and the risk of decline in overall health and physical functioning in late middle age. American Journal of Public Health, 94(9), 1567-1573.

Irwin, J. D. (2007). The prevalence of physical activity maintenance in a sample of university students: A longitudinal study. Journal of American College Health, 56(1), 37-42.

Kerr, J., Eves, F., \& Carroll, D. (2001). Can posters prompt stair use in a worksite environment?. Journal of Occupational Health, 43(4), 205-207.

Leslie, E., Sparling, P. B., \& Owen, N. (2001). University campus settings and the promotion of physical activity in young adults: lessons from research in Australia and the USA. Health Education, 101(3), 116-125.

Lin, S. Y., Davey, R. C., \& Cochrane, T. (2004). Community rehabilitation for older adults with osteoarthritis of the lower limb: a controlled clinical trial. Clinical Rehabilitation, 18(1), 92-101.

Magoc, D., Tomaka, J., \& Bridges-Arzaga, A. (2011). Using the web to increase physical activity in college students. American journal of health behavior, 35(2), 142-154.

Morris, C. K., \& Froelicher, V. F. (1991). Cardiovascular benefits of physical activity. Herz, 16(4), 222-236.

Paffenbarger, R. S., Wing, A. L., Hyde, R. T., \& Jung, D. L. (1983). Physical activity and incidence of hypertension in college alumni. American Journal of Epidemiology, 117(3), 245-257

Paffenbarger Jr, R. S., Hyde, R., Wing, A. L., \& Hsieh, C. C. (1986). Physical activity, all-cause mortality, and longevity of college alumni. New England Journal of Medicine, 314(10), 605-613.

Penedo, F. J., Schneiderman, N., Dahn, J. R., \& Gonzalez, J. S. (2004). Physical activity interventions in the elderly: cancer and comorbidity. Cancer Investigation, 22(1), 5167.

Ross, C. E., \& Hayes, D. (1988). Exercise and psychologic wellbeing in the community. American Journal of Epidemiology, 127(4), 762-771.

Saelens, B. E., Gehrman, C. A., Sallis, J. F., Calfas, K. J., Sarkin, J. A., \& Caparosa, S. (2000). Use of self-management strategies in a 2-year cognitive-behavioral intervention to promote physical activity. Behavior Therapy, 31(2), 365-379.

Smith, S. C., Blair, S. N., Criqui, M. H., Fletcher, G. F., Fuster, V., Gersh, B. J., ... \& Hill, M. N. (1995). Preventing heart attack and death in patients with coronary disease. Journal of the American College of Cardiology, 26(1), 292-292.

Stephens, T. (1988). Physical activity and mental health in the United States and Canada: evidence from four population surveys. Preventive Medicine, 17(1), 35-47.

Tremblay, M. S., Warburton, D. E., Janssen, I., Paterson, D. H., Latimer, A. E., Rhodes, R. E., ... \& Murumets, K. (2011). New Canadian physical activity guidelines. Applied Physiology, Nutrition, and Metabolism, 36(1), 36-46.

Tourangeau, R., Rasinski, K. A., Bradburn, N., \& D'ANDRADE, R. O. Y. (1989). Carryover effects in attitude surveys. Public Opinion Quarterly, 53(4), 495-524.

Warburton, D. E., Nicol, C. W., \& Bredin, S. S. (2006). Prescribing exercise as preventive therapy. Canadian Medical Association Journal, 174(7), 961-974.

Ward, K., \& Hawthorne, K. (1994). Do patients read health promotion posters in the waiting room? A study in one general practice. British Journal of General Practice, 44(389), 583-585.

Wilson, P. M., Rodgers, W. M., Fraser, S. N., \& Murray, T. C. (2004). Relationships between exercise regulations and motivational consequences in university students. Research Quarterly for Exercise and Sport, 75(1), 81-91.

World Health Organization. (2006). The world health report 2006: working together for health. World Health Organization.

How to cite this article: Azmi, Aryan. (2020). The question of participation: an investigation on interventions to increase activity among university students. Eureka University of Alberta Science Undergraduate Research Journal.,5(1), 5-8. https://doi.org/10.29173/eureka28746 


\title{
Young and Risky: Sexual Behaviours Among Generation Z and Millennials
}

\author{
Received: 13 September 2020 \\ Accepted: 28 October 2020 \\ Published: 30 December 2020
}

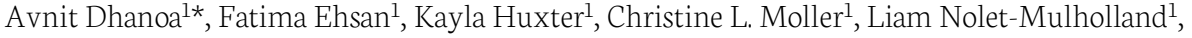 \\ Rimsa Dahal ${ }^{1}$ \\ ${ }^{1}$ Department of Psychology, University of Alberta \\ *Corresponding author: adhanoa@ualberta.ca
}

\begin{abstract}
The purpose of this study was to see if risky sexual behaviour has changed from the Millennial Generation to Generation Z. Data were collected at the University of Alberta from participants ranging in age from 18 to 24 years old. Participants answered 45 multiple choice questions that targeted the use of contraceptives, testing for and history of sexually transmitted infections, unplanned pregnancies, alcohol use, number of sexual partners, first sexual experience, etc. The results of our study suggest that individuals in Generation Z were more likely to participate in sexually risky behaviour in terms of the number of sexual partners. However, there was no significant difference between the two generations in terms of condom use or engagement in sexual activity. Understanding generational changes in sexual risk-taking can better equip communities to provide adequate information and resources to individuals engaging in sexual activity.
\end{abstract}

KEY WORDS: Risky Sexual Behaviour, Millennial, Generation Z, Contraceptives, Sexuality

\section{1 | INTRODUCTION}

Surfing the tops of trains, getting drunk, fighting, having sexual experiences with multiple people, spearfishing in sharkinfested waters, and stealing cars are all examples of risky behaviours. Risky behaviour is defined as a "behaviour which involves potential negative consequences (loss) but is balanced in some way by perceived positive consequences (gain)" (Moore \& Gullone, 1996). Although engaging in risky behaviours is not limited to a particular age group, adolescence (ages 12 to 25) is the developmental period characterized by a high potential for engaging in risky or risk-taking behaviours (Arnett, 1992). According to Arnett (1995), people engage in risky behaviours for reasons such as sensation-seeking, meaning they want to experience new and intense experiences. These experiences can include drinking, partying, and having sexual experiences for the first time. The risky behaviours that people engage in during adolescence can occur in many different ways and often carry through to adulthood, and which may pose physical and health risks to not only themselves but to others (Arnett, 1995).

One possible risky behaviour is risky sexual behaviour which is any behaviour related to a sexual act that places an individual or other individuals in danger. Some examples include intercourse with multiple partners, unprotected sex, and engaging in sexual activity when judgement is impaired.

Engaging in risky sexual behavior is linked to risks of unplanned pregnancies, abortions, and sometimes even associated with depressive symptoms (Ajayi et al., 2017; Othieno et al., 2015). The most well-known consequence of partaking in risky sexual behaviours is contracting sexually transmitted infections (STIs).

The risks of STIs are not only the symptoms that come with the infection but also the complications associated with those infections, such as genital and other cancers, ectopic pregnancy, pelvic inflammatory disease, infertility, and adverse outcomes of pregnancies such as low birth weight and preterm deliveries (Aral, 2001). One concerning factor, for intergenerational differences, is the rise of these infections in recent years. According to Statistics Canada, the three most common infections are chlamydia, gonorrhea, and syphilis (Statistics Canada, 2017). These infections have all had an incredible increase in the past decade. Gonorrhea rates were fairly stable from 2008-2013 but have increased by $96 \%$ in the past 4 years, syphilis rates have increased by $167 \%$ since 2008 , and chlamydia rates increased by 39\% from 2008-2017. (Statistics Canada, 2017). These increases may be due to students' perspectives on STIs 
and the risks of sexual behaviours. Past studies have reported that students show large and serious gaps in their knowledge of sexual health and safe-practices (Downing-Matibag \& Geisinger, 2009). Students often believe that STIs and other consequences of risky sexual behaviours will not happen to them, alluding to a sense of indestructibility (DowningMatibag \& Geisinger, 2009). What makes these statistics even more concerning is the abundance of dating apps available which is commonly said to have caused an increase in "hookup culture".

Hookup culture is incredibly appealing to the undergraduate student population because the majority are in the developmental age where sexual curiosity is heightened (Arnett, 1995). It involves a series of relationships based around casual sex and little long-term, romantic interests. These shortterm relationships with many different partners increase an individual's risk of getting STIs or becoming pregnant as there are more chances for protection to fail. Alcohol influence may play a part in hookup culture as it has been associated with reduced inhibition and increased engagement in risky activity including unsafe sexual practices (Downing-Matibag \& Geisinger, 2009). Since these hookups are often happening in places where protection against STIs are not available or when students' judgments are impaired, such as at university or college parties, it often leads students to participate in riskier sexual behaviors that are compromising to their health (Downing-Matibag \& Geisinger, 2009). In addition to this, sexual orientation and gender play a role in risky sexual activity. Risky sexual activity varies across sexual orientation and gender. Between females and males, gay males have reported higher rates of casual sex encounters than straight males, despite similar levels of interests, whereas females report similar sexual habits and levels of interest regardless of orientation (Eisenberg, 2002; Bailey et al., 1994; Eisenberg et al., 2009). Heterosexual men may have fewer opportunities for casual sex encounters than homosexual men and since sexuality has a wide range, sexuality across this range may vary. According to a Healthline online article by Abrams (2019), heterosexual or straight refers to individuals who experience a sexual, emotional, or romantic attraction to those of the opposite gender. Queer is an umbrella term for those who are not straight, all experiencing the attraction on the same facets previously mentioned. Homosexuality specifically describes individuals who experience attraction toward the same gender, men typically identifying with the label "gay" and women typically identifying with the label "lesbian". Pansexual refers to individuals who experience attraction regardless of the others' identity and bisexuality refers to those attracted to more than one gender. Asexual refers to individuals who experience little-to-no sexual attraction to others, whereas aromantic refers to individuals who exclusively experience little-to-no romantic attraction to others (Abrams, 2019). Because sexuality varies, it is important to acknowledge that sexual practices within these communities may not be unanimous, furthermore, age groups may also exhibit their own practices when it comes to sexual encounters.

Millennials, those born between the years 1981-1995, have a significant amount of research regarding the actions taken to reduce the risk of STIs and unplanned pregnancies, such as condom use. However, less research has been done on the effects of hookup culture, and on the effects of sexuality. For condom use, research has found that Millennials tend to use condoms more often than previous generations, using condoms around 32.2\% of the time (Hunt et al., 2019; Lau et al., 2002). Millennials in a stable relationship tend to use condoms more than those that change relationships frequently, increasing the risks inherent to having multiple partners, such as the increased spread of STIs (Lau et al., 2002). Interestingly, the differences in condom use in the groups were not due to a difference in knowledge about condoms. The reasons listed as to why condoms were not used were that they trust their partner, saw condoms as unnecessary as pregnancies and STIs were not a risk, or because the male partner did not wish to use one (Lau et al., 2002). For STIs in general, research has found that Millennials are less likely to have sexual intercourse if they do not know their partner's sexual health when compared to past generations (Hunt et al., 2019). Hunt et al. (2019) relates this change in behaviour to an increase in prevention strategies for STIs that occurred just before Millennials were born. As for unplanned pregnancy, measured as teenage pregnancy rates, there has been an overall decrease in pregnancy rates in Canada since 1998 (MacKay, 2013; Statistics Canada, 2020). In Alberta specifically, there was a decrease in teenage pregnancy from 2001 to 2005, with rates remaining stable from 2005 to 2010 (MacKay, 2013). This decrease in teenage pregnancy could be due to an increase in access to and use of contraceptives such as condoms. Unfortunately, while Millennials seem to engage in less risky sexual behaviours than previous generations, they still engage in a large number and report seeing risky sexual behavior as an unavoidable necessity (Okafor \& Obi, 2005). It is possible that the generation after Millennials, Generation Z, will have different behaviours as education and discussion about risky sexual behaviours have become even more commonplace.

Generation Z, those born between the years 1995-2015, seem to have had partners more frequently and have shorter relationships than Millennials (Twenge et al., 2015). The 
difference in partners may be due to Millennials often choosing marriage over cohabitation as premarital sex was only accepted by $62 \%$ of young adult Millennials (Johnson et al., 2001; Twenge et al., 2015). Of course, simply knowing how generations differ in preferred relationship types, does not tell us how they differ in risky behaviors within those relationships.

In our study, we tested if risky sexual behaviour has changed from the Millennial generation to Generation Z. As well, we explored the number of sexual partners, sexual orientation, and condom and drug use specifically within Generation Z. Our study mainly addresses whether risky sexual behaviours have increased or decreased between the two generations. Data were collected at the University of Alberta from participants ranging from ages 18 to 24 years old. The independent variables in this study include gender, sexuality, and age. As gender is becoming more common in science to describe biological variations assigned to sex, we decided to base our analysis on gender instead of sex (Torgrimson \& Minson, 2005). Here, fender is defined as the cultural, behavioural or psychological traits that are associated with one's sex (Torgrimson \& Minson, 2005). Basing our analysis on gender allows for a more selfrepresentative view of our results rather than basing it on sex, the latter of which may have allowed for a reproductive/biological view. The dependent variable in this study is risky sexual behaviour. We compared Millennials and Generation Z participants on a variety of different risky sexual behaviours including the number of sexual partners, engagement in sexual activity under the influence, and condom use. For generational differences, we had three different hypotheses. Firstly, we hypothesized that the number of sexual partners has decreased in Generation Z compared to Millennials. Secondly, we also hypothesized that sexual intercourse while being intoxicated have decreased in Generation $Z$ compared to Millennials. Finally, we hypothesized that risky sexual behaviours such as not using condoms have decreased in Generation Z compared to Millennials. As for sexual behaviors within Generation Z, we hypothesized that Generation $\mathrm{Z}$ would have a low number of sexual partners, would have cross sexuality differences, and have a low occurrence of sexual intercourse without condoms while intoxicated.

\section{2 | METHODS}

\section{Participants}

A total of 120 responses were collected for Generation Z from participants that range from age 18 years to 24 years old (those born between 2001 and 1995). One participant was excluded because they chose not to disclose information to a majority of questions we referred to for the analysis. Participants were recruited via the UofA Student Digest forum, Undergraduate Research Initiative forum, poster advertising, emails to professors that are then forwarded to students, and presentations to students at the University of Alberta during 2020. All individuals were aware of the content being examined, as the study was advertised as examining risky sexual behaviours.

Table 1. Characteristics of the Student Sample

\begin{tabular}{|c|c|c|c|c|c|c|}
\hline & \multicolumn{2}{|c|}{ Female } & \multicolumn{2}{|c|}{ Male } & \multicolumn{2}{|c|}{ Total } \\
\hline & $\mathrm{n}$ & $\%$ & $\mathrm{n}$ & $\%$ & $\mathrm{n}$ & $\%$ \\
\hline Gender & 95 & 80.5 & 23 & 19.5 & 118 & 99.2 \\
\hline \multicolumn{7}{|l|}{ Sexuality } \\
\hline Straight & 68 & 73.1 & 16 & 76.2 & 84 & 73.7 \\
\hline Gay & & - & 2 & 9.5 & 2 & 1.8 \\
\hline Lesbian & 4 & 4.3 & - & & 4 & 3.5 \\
\hline Bisexual & 12 & 12.9 & 2 & 9.5 & 14 & 12.3 \\
\hline Queer & 2 & 2.2 & 1 & 4.8 & 3 & 2.6 \\
\hline Asexual Spectrum & 2 & 2.2 & - & - & 2 & 1.8 \\
\hline Pansexual Spectrum & 2 & 2.2 & - & - & 2 & 1.8 \\
\hline Aromantic Spectrum & 1 & 1.1 & - & - & 1 & 0.88 \\
\hline Questioning & 1 & 1.1 & - & - & 1 & 0.88 \\
\hline Biromantic & 1 & 1.1 & - & - & 1 & 0.88 \\
\hline \multicolumn{7}{|l|}{ General Condom Use } \\
\hline $\begin{array}{l}\text { Have never been } \\
\text { sexually active }\end{array}$ & 28 & 29.8 & 7 & 31.8 & 35 & 30.2 \\
\hline Never (0\%) & 13 & 13.8 & 2 & 9.1 & 15 & 12.9 \\
\hline Rarely (1-25\%) & 15 & 16 & 2 & 9.1 & 17 & 14.7 \\
\hline $\begin{array}{l}\text { Sometimes } \\
(25-50 \%)\end{array}$ & 7 & 7.4 & 2 & 9.1 & 9 & 7.8 \\
\hline $\begin{array}{l}\text { Often } \\
(51-75 \%)\end{array}$ & 6 & 6.4 & 2 & 9.1 & 8 & 6.9 \\
\hline $\begin{array}{l}\text { Always } \\
(76-100 \%)\end{array}$ & 25 & 26.6 & 7 & 31.8 & 32 & 27.6 \\
\hline \multicolumn{7}{|l|}{$\begin{array}{c}\text { Number of Sexual } \\
\text { Partners }\end{array}$} \\
\hline None & 29 & 30.5 & 7 & 31.8 & 36 & 30.8 \\
\hline $1-2$ & 41 & 43.2 & 5 & 22.7 & 46 & 39.3 \\
\hline $3-4$ & 11 & 11.6 & 3 & 13.6 & 14 & 12.0 \\
\hline $5-6$ & 4 & 4.2 & 1 & 4.5 & 5 & 4.3 \\
\hline$>6$ & 10 & 10.5 & 6 & 27.3 & 16 & 13.6 \\
\hline
\end{tabular}

${ }^{1}$ In lifetime

\section{Materials and Procedures}

The participants answered a 45-question, modified version of Okafor and Obi (2005)'s anonymous multiple-choice questionnaire (Appendix A) that targeted the use of contraceptives, testing for and history of sexually transmitted infections, unplanned pregnancies, alcohol use, number of 
sexual partners, first sexual experience, etc. Participants completed the questionnaire anonymously via Google Forms. Data for the Millennial generation was taken from a previous study conducted by Eisenberg (2001).

The independent variables in this study include gender (male, female or non-binary), sex (male, female or intersex), sexuality (straight, gay, bisexual, queer, asexual spectrum, pansexual, aromantic spectrum or other) and age (18-20 years, 20-22 years or 22-24 years). The dependent variable is risky sexual behaviours. Risky sexual behaviours include any actions which place an individual at a higher risk of unplanned pregnancies, STIs, and other negative consequences. Examples of risky sexual behaviours examined in this study include not using condoms/contraceptives, not getting tested for STIs, and having many sexual partners. Answers were scored using a scale from 0-5. Responses scored 0 included individuals who reported never having been sexually active or those who responded never having participated in the risky behaviour in the question. The perceived riskiness is determined by the increasing value of the score. A score of 5 was given to the responses that were subjectively determined to be the most risky.

Chi-squared tests of independence were conducted to determine whether there was a significant difference between the two generations. These tests were completed by comparing Eisenberg (2001)'s Millennial data with the data obtained from this study (Generation Z). Chi-squared tests were also used to examine the significance of variables solely within Generation Z.

\section{3 | RESULTS}

\section{General Characteristics}

The table below summarizes the distribution of responses on condom use, number of sexual partners, and sexuality by gender (Table 1). Notably, $80 \%$ of our participants (Generation $\mathrm{Z}$ ) were female and over 30\% reported to have never been sexually active. Over $70 \%$ of all participants were straight.

\section{Generational Differences}

Number of Sexual Partners. We examined the number of sexual partners between Generation Z and the Millennial generation. The relation between these variables was significant, $X^{2}(2, N=8768)=415.13, p<.00001$ (Table 2). When looking at Generation Z versus the Millennials, 33\% of Generation Z participants were considered to be exhibiting risky sexual behaviour (having 3 or more partners) whereas only $2.5 \%$ of Millennial participants were considered to be exhibiting risky sexual behaviour. This result suggests that the individuals in Generation Z were more likely to participate in risky sexual behaviour than Millennials, in terms of the number of partners. Similarly, the proportion of subjects who reported engaging in sexual activity in Generation Z did not differ from the proportion of subjects who reported engagement in sexual activity in the Millennial Generation, X2 $(1, \mathrm{~N}=13235)=.0817, \mathrm{p}=0.77$ (Table 2). Lastly, we examined condom use between Generation Z and Millennials. The relationship between the variables was not significant X2 (3, $8737)=3.65, \mathrm{p}=.30$; meaning there is no significant difference between the two generations when looking at condom use (Table 2).

Table 2. Characteristics of the Student Sample

\begin{tabular}{cccccc}
\hline \hline & & \multicolumn{2}{c}{ Generation Z } & \multicolumn{2}{c}{ Millennials $^{1}$} \\
\cline { 3 - 6 } & & $\mathrm{n}$ & $\%$ & $\mathrm{n}$ & $\%$ \\
\hline $\begin{array}{c}\text { Number of } \\
\text { Sexual } \\
\text { Partners }\end{array}$ & $1-2$ & 46 & 39 & 5859 & 67.7 \\
\hline $\begin{array}{c}\text { Engagement } \\
\text { in Sexual }\end{array}$ & Yctivity & 40 & 33.9 & 212 & 2.5 \\
\hline & No & 36 & 30.5 & 3844 & 29.3 \\
\hline $\begin{array}{c}\text { Condom } \\
\text { Use }\end{array}$ & Rarely & 14 & 17.7 & 1013 & 11.7 \\
& Sometimes & 18 & 22.7 & 1781 & 20.6 \\
& Always & 32 & 40.5 & 3798 & 43.9 \\
\hline
\end{tabular}

${ }^{1}$ Millennial generation data was taken from Eisenberg (2001)

\section{Within Generation Z}

Number of Sexual Partners. Within Generation Z, there was a significant association between the age of first sexual activity and the number of sexual partners, $X^{2}(16, N=116)=131.11, p<$ .00001 (Table 3). As well, we examined the relationship between STI history and the number of sexual partners. The relation between these variables was not significant, $X^{2}(1, N=119)=1.78$, $p=.18$. However, this result could be skewed by the small sample of individuals with a history of STIs.

Sexual Orientation. Our results suggest that more straight females rarely or never use condoms (31.8\%) than always use condoms (27.3\%) (Table 3). All sexually active lesbian and pansexual females never use condoms while all sexually active asexual, queer, and aromantic females always used condoms. Approximately one-third of bisexual females always use condoms while no bisexual females never use condoms. $25 \%$ of both straight and lesbian females had a risky number of sexual

Eureka || 16 
Table 3. Characteristics of condom use according to gender: Sexuality and age at which sex life began (in years)

\begin{tabular}{|c|c|c|c|c|c|c|c|c|c|c|c|c|c|c|c|c|c|c|c|c|c|}
\hline & & \multicolumn{20}{|c|}{ Condom Use } \\
\hline & & \multicolumn{4}{|c|}{ None } & \multicolumn{4}{|c|}{$1-2$} & \multicolumn{4}{|c|}{$3-4$} & \multicolumn{4}{|c|}{$5-6$} & \multicolumn{4}{|c|}{$>6$} \\
\hline & & \multicolumn{2}{|c|}{ Female } & \multicolumn{2}{|c|}{ Male } & \multicolumn{2}{|c|}{ Female } & \multicolumn{2}{|c|}{ Male } & \multicolumn{2}{|c|}{ Female } & \multicolumn{2}{|c|}{ Male } & \multicolumn{2}{|c|}{ Female } & \multicolumn{2}{|c|}{ Male } & \multicolumn{2}{|c|}{ Female } & \multicolumn{2}{|c|}{ Male } \\
\hline & & $\mathrm{n}$ & $\%$ & $\mathrm{n}$ & $\%$ & $\mathrm{n}$ & $\%$ & $\mathrm{n}$ & $\%$ & $\mathrm{n}$ & $\%$ & $\mathrm{n}$ & $\%$ & $\mathrm{n}$ & $\%$ & $\mathrm{n}$ & $\%$ & $\mathrm{n}$ & $\%$ & $\mathrm{n}$ & $\%$ \\
\hline \multirow{10}{*}{ 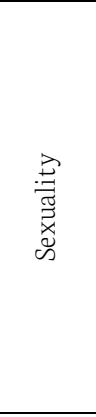 } & Straight & 20 & 74.1 & 6 & 100 & 31 & 75.6 & 4 & 80 & 9 & 81.8 & 3 & 100 & 4 & 100 & - & - & 4 & 40 & 3 & 0.5 \\
\hline & Gay & - & 0 & - & - & - & - & - & - & - & - & - & - & - & 0 & - & - & - & - & 2 & 33.3 \\
\hline & Lesbian & 1 & 3.7 & - & - & 2 & 4.9 & - & - & - & - & - & - & - & 0 & - & - & 1 & 10 & - & - \\
\hline & Bisexual & 1 & 3.7 & - & - & 5 & 12.2 & 1 & 20 & 2 & 18.2 & - & - & - & 0 & 1 & 100 & 4 & 40 & - & - \\
\hline & Queer & 1 & 3.7 & - & - & 1 & 2.4 & - & - & - & - & - & - & - & 0 & - & - & - & - & 1 & 16.7 \\
\hline & Asexual Spectrum & 1 & 3.7 & - & - & 1 & 2.4 & - & - & - & - & - & - & - & - & - & - & - & - & - & - \\
\hline & Pansexual Spectrum & 1 & 3.7 & - & - & - & - & - & - & - & - & - & - & - & - & - & - & 1 & 10 & - & - \\
\hline & Aromantic Spectrum & - & 0 & - & - & 1 & 2.4 & - & - & - & - & - & - & - & - & - & - & - & - & - & - \\
\hline & Questioning & 1 & 3.7 & - & - & - & - & - & - & - & - & - & - & - & - & - & - & - & - & - & - \\
\hline & Biromantic & 1 & 3.7 & - & - & - & - & - & - & - & - & - & - & - & - & - & - & - & - & - & - \\
\hline \multirow{8}{*}{ 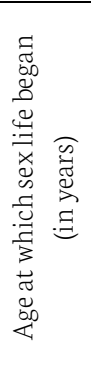 } & $\begin{array}{l}\text { Never been sexually } \\
\text { active }\end{array}$ & 29 & 100 & 7 & 100 & - & - & - & - & - & - & - & - & - & - & - & - & - & - & - & - \\
\hline & Under 12 & - & - & - & - & - & - & - & - & - & - & - & - & - & - & - & - & - & - & - & - \\
\hline & $12-14$ & - & - & - & - & 1 & 2 & 1 & 20 & - & - & - & - & - & - & - & - & 2 & 20 & - & - \\
\hline & $15-16$ & - & - & - & - & 7 & 13.7 & 1 & 20 & 5 & 45.5 & 2 & 66.7 & 1 & 33.3 & - & - & 5 & 50 & 2 & 33.2 \\
\hline & $17-18$ & - & - & - & - & 19 & 37.3 & 3 & 60 & 4 & 36.4 & 1 & 33.3 & 2 & 66.7 & 1 & 100 & 2 & 20 & 4 & 66.7 \\
\hline & $19-20$ & - & - & - & - & 10 & 19.6 & - & - & 2 & 18.2 & - & - & - & - & - & - & 1 & 10 & - & - \\
\hline & $21-22$ & - & - & - & - & 3 & 5.9 & - & - & - & - & - & - & - & - & - & - & - & - & - & - \\
\hline & $23-24$ & - & - & - & - & 1 & 2 & - & - & - & - & - & - & - & - & - & - & - & - & - & - \\
\hline
\end{tabular}

partners (greater than 3). 41.7\% of bisexual females had a risky number of sexual partners. No queer, asexual, and aromantic females had a risky number of sexual partners. Finally, 50\% of pansexual females had a risky number of sexual partners. Condom and Drug Use. Similarly, when looking at Generation $Z$, there was a significant association between condom use and alcohol consumption before sexual intercourse, $X^{2}(8, N=117)$ $=126.91, p<.00001 .19 .1 \%$ of individuals who reported consuming alcohol before sexual intercourse reported never or rarely using condoms (Table 4). In contrast, only $7.7 \%$ of individuals who reported not consuming alcohol before sexual intercourse reported never using condoms and 30.8\% of individuals who said no to consuming alcohol rarely used condoms. Here we can see that individuals who consume alcohol before sexual intercourse are more likely to engage in risky sexual behaviour when compared to individuals who

Table 4. Alcohol and Drug Consumption before Sexual Intercourse in Relation to Condom Use within Generation Z

\begin{tabular}{|c|c|c|c|c|c|c|c|c|c|}
\hline & & \multicolumn{4}{|c|}{$\begin{array}{c}\text { Alcohol } \\
\text { Consumed }\end{array}$} & \multicolumn{4}{|c|}{ Drugs Consumed } \\
\hline & & \multicolumn{2}{|c|}{ Yes } & \multicolumn{2}{|c|}{ No } & \multicolumn{2}{|c|}{ Yes } & \multicolumn{2}{|c|}{ No } \\
\hline & & $\mathrm{n}$ & $\%$ & $\mathrm{n}$ & $\%$ & $\mathrm{n}$ & $\%$ & $\mathrm{n}$ & $\%$ \\
\hline \multirow{4}{*}{ 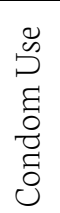 } & Never & 13 & 19.1 & 1 & 7.7 & 7 & 24.1 & 7 & 14 \\
\hline & Rarely & 13 & 19.1 & 4 & 30.8 & 5 & 17.2 & 12 & 24 \\
\hline & Often & 18 & 26.5 & - & - & 10 & 34.5 & 18 & 16 \\
\hline & Alway & 24 & 35.3 & 8 & 61.5 & 7 & 24.1 & 23 & 46 \\
\hline
\end{tabular}

report no alcohol consumption before intercourse. Likewise, there was a significant association between condom use and drug consumption before sexual intercourse, $X^{2}(8, N=115)=$ 124.49, $p<.00001 .24 .1 \%$ of individuals who reported using drugs before sexual intercourse reported never using condoms and $17.2 \%$ of individuals reported rarely using condoms. In contrast, only $14 \%$ of individuals who reported not using drugs before sexual intercourse reported never using condoms and $24 \%$ of individuals who reported no to using drugs reported they rarely used condoms. Here we can see that individuals who use drugs before sexual intercourse are more likely to engage in risky sexual behaviour when compared to individuals who report no drug consumption before intercourse.

\section{4 | DISCUSSION}

In our introduction, we hypothesized that Generation Z would have less risky sexual behaviours compared to Millennials. After completing the analysis, we discovered that Generation Z exhibited more sexually risky behaviour, in terms of a greater number of sexual partners, when compared to the Millennials. A possible explanation for the increase in the number of sexual partners from the Millennial generation to Generation Z could be the promotion and popularization of "hook-up culture" that was discussed earlier (Arnett, 1995). By choosing to engage in relationships centered around casual sex rather than long-term emotional commitments, individuals are more likely to have a larger number of sexual partners (Arnett, 1995). Furthermore, the increase in risky sexual behaviour could be related to an 
earlier onset of puberty over generations (Eveleth \& Tanner, 1990; Meng et al., 2017; Mendle \& Ferrero, 2012; HermanGiddens et al., 2012). While the onset of puberty was not measured in this study, two factors that are related to earlier puberty (earlier first sexual activity and a greater number of partners) were associated with each other which suggests that individuals in this study may have had an earlier onset of puberty (Boden et al., 2011; Baams et al., 2015; Kogan et al., 2014). In other words, Generation Z may have had a greater number of partners because of the worldwide shift towards earlier puberty.

It is important to remember that having a greater number of sexual partners is only considered risky if condoms and other contraceptives are not consistently used. At first glance, it appeared as though members of Generation $Z$ tend to use condoms and other preventative measures as very few participants reported a history of STIs or unplanned pregnancies. Unfortunately, those that had a greater number of sexual partners did not follow this trend. $38.5 \%$ of the females who had 3 or more sexual partners reported never using a condom while only $24 \%$ reported always using a condom. There are a few possible explanations as to why the STI and unplanned pregnancy rates are so low in this sample despite the low use of condoms. Firstly, as there were separate questions regarding the use of contraceptives other than condoms, those that did not use condoms may have used other forms of protection, and although all contraceptive methods are designed to prevent unintended pregnancies, some methods are more effective than others. The most common form of contraception for women between the ages of 15 and 44 is the birth control pill, condoms, and withdrawal (Daniels et al, 2015). Secondly, we did not control for women who engaged in same-sex sexual intercourse that would not have used condoms. Given that $21.6 \%$ of our female participants identify as a sexuality where they are likely to have same-sex sexual intercourse, this may be an important factor. As all lesbians and pansexual females that had been sexually active reported never using condoms and only one-third of bisexual females, in general, reported always using condoms, these individuals could easily be the cause of the low condom rates reported. Recent findings by Blunt-Vinti et al. (2018) have shown that the rates of contraceptive use among college women vary significantly between different sex-oriented groups. Straight women are significantly more likely to use at least a moderate form of contraceptives compared to bisexual, pansexual, and queer women. Furthermore, women who identify as asexual and lesbian were also significantly less likely to use highly efficient contraceptive methods (LARCS) compared to straight women.
Stanley et al. (2019) conducted a study where they look at the credibility and completeness of the sexual health information available to young adults through Student Health Center (SHC) websites across 400 randomly selected colleges and universities. The study found that most SHC websites do not provide complete sexual health information to students. Only 9\% of post-secondary institutions had a separate tab dedicated to sexual health but $80 \%$ did not, instead they only mentioned sexual health. This is problematic and deeply alarming because not only does this lack of completeness decrease the credibility of SHCs among students, but it leaves students who rely more on online resources for sexual health information at a higher risk. For example, African American students are more likely to use the internet for birth control information compared to white students, and gay, lesbian, and bisexual students whose sexual concerns are not sufficiently addressed by school-based education are more likely to rely on the internet for sexual health information (Fogel et al., 2010). Studies have shown that when students are looking for sexual health information online, they are more likely to turn to less reliable sources of information if reliable information is difficult to locate (Buhi et al., 2009). Altogether, the research suggests that there is still a strong need for accessible, equitable, and complete sexual health information by students in order to ensure safe sexual practices and to reduce risky sexual behaviours students may partake in as a result of a lack of reliable information. Another factor that affected condom use was the consumption of alcohol or drugs.

Generation Z individuals are significantly less likely to use condoms after consuming alcohol or drugs. It is incredibly worrying that $81.9 \%$ of individuals who have had sexual intercourse have consumed alcohol before or during intercourse. One reason for this high consumption of alcohol before sex among Generation Z may be that our sample consisted of university students. University students tend to consume larger quantities of alcohol more frequently when compared to other age groups, which can lead to more situations where both sexual intercourse and alcohol consumption can occur together (Statistics Canada, 2020). The high percentage of individuals in this study who reported consuming alcohol, and the strong negative effect of alcohol and drug consumption on condom use, suggests that programs need to be created to teach adolescents about the dangers of having sexual intercourse when under the influence of alcohol and/or drugs. Not only is educating individuals on the dangers of sexual activity when under the influence important because of consent-related issues but also because of the increased risk of STIs and pregnancy due to lack of condom use. 


\section{5 | CONCLUSIONS}

Our study tested if risky sexual behaviour has changed from the Millennial generation to Generation Z. Within Generation $Z$, we accounted for the number of sexual partners, sexual orientation, and condom and drug use. The results of our study demonstrate that Generation Z exhibits higher risky sexual behavior compared to Millennials, which was contrary to our hypothesis. However, there was no significant difference between Generation $Z$ and Millennials when looking at the engagement in sexual history. Generation Z individuals had a higher number of sexual partners compared to Millennials. Within the sample of Generation Z, those who had a higher number of sexual partners used condoms less frequently. Also, after consuming alcohol or drugs, Generation Z individuals are less likely to use condoms. The results regarding condoms were also contrary to our hypothesis, as we thought Generation Z would have a lower occurrence of sexual intercourse without condom use while being intoxicated. Our study tested if risky sexual behavior has changed from the Millennial generation to Generation Z. Within Generation Z, we accounted for the number of sexual partners, sexual orientation, and condom and drug use. The results of our study demonstrate that Generation Z exhibits higher risky sexual behaviour compared to Millennials, which was contrary to our hypothesis. However, there was no significant difference between Generation $\mathrm{Z}$ and Millennials when looking at the engagement in sexual history. Generation Z individuals had a higher number of sexual partners compared to Millennials. Within the sample of Generation Z, those who had a higher number of sexual partners used condoms less frequently. Also, after consuming alcohol or drugs, Generation Z individuals are less likely to use condoms. The results regarding condoms were also contrary to our hypothesis, as we thought Generation Z would have a lower occurrence of sexual intercourse without condom use while being intoxicated.

\section{Limitations}

This study recruited participants through a convenience sampling method, which was chosen due to the sensitivity of the subject we are investigating. However, this sampling method raises some questions about the representativeness of the sample. First off, in terms of generalizability, our sample consisted only of University of Alberta students, therefore, its generalizability extends only to students of this institution and is not representative of other universities. Secondly, this sample is not representative of other 18-to-24-year-olds (not attending universities) in the Edmonton area as university students may have more access to resources promoting safe sexual practices. Thirdly, by splitting our sample into multiple different categories, we were unable to see large effect sizes between
Generation Z and Millennials. Another limitation in our study was the reliability and validity of the modified questionnaire as Okafor and Obi (2005) did not provide information on this. Lastly, our study consisted mainly of female participants, so future research should aim to involve a more comprehensive sample.

\section{Future Research}

The difficulty of comparing Generation Z to Millennials stemmed from a variable definition of who the Millennials are. When defining the Millennial generation, previous studies often split and group the Millennials into older and/or younger generations. For this reason, any research with clear cut age demographics would be of benefit. In our study, we found that over half of all participants who reported being sexually active had never been checked for an STI and 19.2\% had never asked their partner about their history of STIs. Evidently, safe sexual practices can and should still be improved. Looking into the best way to improve on safe sexual practices should be further investigated in post-secondary institutions. We speculate that the impact of safe sex advertisements may be dwindling due to the oversaturation of the same message over time.

\section{AUTHOR CONTRIBUTIONS}

All authors contributed equally to this work.

\section{ACKNOWLEDGEMENTS}

We would like to thank the University of Alberta for offering research specific programs and allowing us to conduct this study. We thank Dr. Elena Nicoladis for mentoring us through our first research experience and to Emily Beaulieu and Alice Atkin for their feedback.

\section{REFERENCES}

Abrams, M. (2019, December 10). 46 Terms That Describe Sexual Attraction, Behavior \& Orientation. Retrieved October 25, 2020, from https://www.healthline.com/health/different-types-ofsexuality

Ajayi, A. I., Nwokocha, E. E., Akpan, W., Adeniyi, O. V., \& Goon, D. T. (2017). "It's sweet without condom": Understanding risky sexual behaviour among Nigerian Female University students. Online Journal of Health and Allied Sciences, 16(4), 9.

Aral, S. O. (2001). Sexually transmitted diseases: Magnitude, determinants and consequences. International Journal of STD \& AIDS, 12(4), 211-215. https://doi.org/10.1258/0956462011922814 
Arnett, J. (1992). Reckless behavior in adolescence: A developmental perspective. Developmental review, 12(4), 339-373. https://doi.org/0273-2297/92

Arnett, J. (1995). The young and the reckless: Adolescent reckless behavior. Current Directions in Psychological Science, 4(3), 67-70.

Baams, L., Dubas, J. S., Overbeek, G., \& Aken, M. A. V. (2015).

Transitions in body and behavior: A meta-analytic study on the relationship between pubertal development and adolescent sexual behavior. Journal of Adolescent Health, 56(6), 586-598. https://doi.org/10.1016/j.jadohealth.2014.11.019

Bailey, J. M., Gaulin, S., Agyei, Y., \& Gladue, B. A. (1994). Effects of gender and sexual orientation on evolutionarily relevant aspects of human mating psychology. Journal of Personality and Social Psychology, 66(6), 1081-1093. https://doi.org/10.1037/0022-3514.66.6.1081

Blunt-Vinti, H. D., Thompson, E. L., \& Griner, S. B. (2018). Contraceptive Use Effectiveness and Pregnancy Prevention Information Preferences Among Heterosexual and Sexual Minority College Women. Women's Health Issues, 28(4), 342-349. https://doi.org/10.1016/j.whi.2018.03.005

Boden, J. M., Fergusson, D. M., \& Horwood, L. J. (2011). Age of menarche and psychosocial outcomes in a New Zealand birth cohort. Journal of the American Academy of Child \& Adolescent Psychiatry, 50(2). https://doi.org/10.1016/j.jaac.2010.11.007

Daniels, K., Daugherty, J. D., \& Mosher, W. D. (2015). Current contraceptive use and variation by selected characteristics among women aged 15-44: United States, 2011-2013. Natl Health Stat Report, 10(86), 1-14.

Downing-Matibag, T. M., \& Geisinger, B. (2009). Hooking up and sexual risk taking among college students: A health belief model perspective. Qualitative Health Research (19) 9, 1196-1209. https://doi.org/10.1177/1049732309344206

Eisenberg, M. E. (2001) Differences in sexual risk behaviors between college students with same-sex and oppositesex experience: Results from a national survey. Archives of Sexual Behavior, (30), 575-589. https://doi.org/https://doi.org/10.1023/A:10119

Eisenberg, M. E. (2002). The association of campus resources for gay, lesbian, and bisexual students with college students' condom use. Journal of American College Health, 51(3), 109-116. https://doi.org/10.1080/07448480209596338

Eisenberg, M. E., Ackard, D. M., Resnick, M. D., \& NeumarkSztainer, D. (2009). Casual sex and psychological health among young adults: Is having "friends with benefits" emotionally damaging? Perspectives on Sexual and Reproductive Health, 41(4), 231-237. https://doi.org/10.1363/4123109

Buhi, E., Daley, E., Fuhrmann, H., \& Smith, S. (2009). An observational study of how young people search for online sexual health information. Journal of American College Health, 58(2), 101-111, https://doi.org/10.1080/07448480903221236

Eveleth, P., \& Tanner, J. (1990). Worldwide variation in human growth (2nd ed.). New York: Cambridge University Press.

Fogel, J., Fajiram, S., \& Morgan, P. (2010). Sexual health information seeking on the Internet: comparisons between White and African American college students. ABNF Journal, 21(4), 79.

Herman-Giddens, M.E., Steffes, J., Harris, D., Slora, E., Hussey, M., Dowshen, S.A., Wasserman, R., Serwint, J.R., Smitherman, L., \& Reiter, E.O. (2012). Secondary sexual characteristics in boys: Data from the Pediatric Research in Office Settings Network. Pediatrics, 130(5). https://doi.org/10.1542/peds.2011-3291

Hunt, G., Wang, L., Bacani, N., Card, K., Sereda, P., Lachowsky, N., Roth, E., Hogg, R., Moore, D., \& Armstrong, H. (2019). Generational differences in sexual behaviour and partnering among gay, bisexual, and other men who have sex with men. The Canadian Journal of Human Sexuality, 28(2), 215-225. https://doi.org/10.3138/cjhs.2019-0014

Johnson, A. M., Mercer, C. H., Erens, B., Copas, A. J., McManus, S., Wellings, K., Fenton, K.A., Korovessis, C., Macdowall, W., Nanchahal, K., Purdon, S., \& Field, J. (2001). Sexual behaviour in Britain: Partnerships, practices, and HIV risk behaviours. The Lancet, 358, 1835-1842. https://doi.org/10.1016/S0140-6736(01)068830

Kogan, S. M., Cho, J., Simons, L. G., Allen, K. A., Beach, S. R. H., Simons, R. L., \& Gibbons, F. X. (2014). Pubertal timing and sexual risk behaviors among rural African American male youth: Testing a model based on life history theory. Archives of Sexual Behavior, 44(3), 609618. https://doi.org/10.1007/s10508-014-0410-3

Lau, J, Tang, A, Siah, P, \& Tsui, H (2002). Assessment of HIVrelated sexual risk behaviors among the general female population in Hong Kong. Archives of Sexual Behavior, 31(6), 535-542. https://doi.org/00040002/02/1200-0535/0

Mendle, J., \& Ferrero, J. (2012). Detrimental psychological outcomes associated with pubertal timing in 
adolescent boys. Developmental Review, 32(1), 49-66. https://doi.org/10.1016/j.dr.2011.11.001

Meng, X., Li, S., Duan, W., Sun, Y., \& Jia, C. (2017). Secular trend of age at menarche in Chinese adolescents born from 1973 to 2004. Pediatrics, 140(2). https://doi.org/10.1542/peds.2017-0085

Moore, S., \& Gullone, E. (1996). Predicting adolescent risk behavior using a personalized cost-benefit analysis. Journal of Youth and Adolescence, 25(3), 343-359. https://doi.org/10.1007/bf01537389

Okafor \& S. N. Obi (2005) Sexual risk behaviour among undergraduate students in Enugu, Nigeria, Journal of Obstetrics and Gynaecology, 25(6), 592-595, https://doi.org/10.1080/01443610500239511

Othieno, C. J., Okoth, R., Peltzer, K., Pengpid, S., \& Malla, L. O. (2015). Risky HIV sexual behaviour and depression among University of Nairobi students. Annals of General Psychiatry, 14(1), 1-8. https://doi.org/10.1186/s12991-015-0054-2
Statistics Canada (2017). Report on sexually transmitted infections in Canada, 2017, syphilis, gonorrhea, chlamydia.

Statistics Canada (2020). Teen pregnancy rates, by pregnancy outcomes, females aged 15 to 19

Stanley, S. J., Yan, K., Jiao, J., Lutovsky, B. R., Aubrey, J. S., \& Pitts, M. J. (2019). Communicating about sex when it matters: A content analytic investigation of sexual health information on college student health center websites. Journal of Applied Communication Research, 47(5), 591-610. https://doi.org/10.1080/00909882.2019.1675895

Torgrimson, B. N., \& Minson, C. T. (2005). Sex and gender: What is the difference? Journal of Applied Physiology,99(3), 785-787. https://doi.org/10.1152/japplphysiol.00376.2005

Twenge, J. M., Sherman, R. A., \& Wells, B. E. (2015). Changes in American adults' sexual behavior and attitudes, 19722012. Archives of Sexual Behavior, 44(8), 2273-2285. https://doi.org/10.1007/s10508-015-0540-2

How to cite this article: Dhanoa, A., Ehsan, F., Huxter, K., Moller, C. L., Nolet-Mulholland, L., Dahal, R. (2020). Young and risky: Sexual behaviours among Generation Z and Millennials. Eureka University of Alberta Science Undergraduate Research Journal, 5(1). https://doi.org/10.29173/eureka28749 


\section{A Tale of Two Frames: A Study on the Effects of Framed Health Messages on Autonomous Motivation for Physical Activity}

Received: 12 November 2020

Accepted: 21 December 2020

Published: 30 December 2020

\author{
Aryan Azmi ${ }^{1 *} \&$ Cristiane B. Cruz ${ }^{2}$ \\ ${ }^{1}$ School of Public Health, University of Alberta, ${ }^{2}$ Faculty of Kinesiology \& Physical Education, \\ University of Toronto \\ *Corresponding author: aazmi@ualberta.ca
}

\section{ABSTRACT}

Background An area of interest for physical activity promotion has been the use of persuasive messages, specifically, the use of framing effects as a method of persuasive communication. One theory that has been used to investigate the mechanisms through which framed health messages affect physical activity motivation is the Self-Determination Theory (SDT). This study uses the SDT to investigate the effects of framed health messages on autonomous motivation for physical activity.

Methods 107 York University undergraduate students ( $N=107 ; 51$ females, 56 males) ages 18 - 30 were recruited from the school of Kinesiology and Health Sciences. Participants were randomly assigned to one of three message groups: gain-framed, loss-framed and control. They were given and instructed to read the messages. Afterwards, the participants' autonomous motivation levels were measured.

Results No significant difference in autonomous regulation levels were observed between the three frame groups. However, a significant interaction was shown between participants' gender and frame condition; among the female participants, levels of autonomous regulation were significantly higher in the loss frame group, when compared to the control group.

Conclusions Based on the results of this study, women who were exposed to loss-framed messages tended to demonstrate higher levels of autonomy. Similar framing effects were not evident in males.

KEY WORDS: Self-Determination Theory, Physical Activity Promotion, Health Promotion, Framed Health Messages, Autonomous Motivation

\section{1 | INTRODUCTION}

The Greek philosopher Plato stated: "In order for man to succeed in life, God provided him with two means, education and physical activity". May Plato's God smile favorably upon us as we attempt to further educate ourselves about physical activity.

The health benefits of physical activity are undeniable (Paffenbarger et al., 1986; Chandrashekhar, \& Anand, 1991; Smith et al., 1995; Uusitupa et al., 2000; He \& Baker, 2004). The unfortunate reality, however, is that it has been shown that only $15 \%$ of Canadian adults engage in adequate levels of physical activity (Colley et al., 2011). Hence, the next logical step would be to study how we can increase physical activity participation. To this end, researchers have been thoroughly engaged in the field of physical activity promotion through the use of persuasive messages. One particular area of interest is the study of framing effects as a method of persuasive communication. The frame of a message reflects the emphasis of that message: a gain frame highlights the benefits of an activity, whereas a loss frame points out the costs of not engaging (Latimer et al, 2010). Regarding the effects of physical activity, an example of a gain-framed message can be "if you engage in physical activity, you will have improved health", whereas a loss-framed message can resemble "if you do not engage in physical activity, your health will suffer".

Framed messages have been extensively researched within the field of physical activity psychology; these studies have produced varying results with regards to physical activity promotion, with some studies showing greater impact of gainframed messages on physical activity levels (Latimer et al., 2008; Latimer et al. 2010; Gallagher, \& Updegraff, 2012) and some demonstrating the greater impact of loss-framed messages (Bassett-Gunter et al., 2013). Furthermore, research on 
the underlying mechanisms by which the framed messages exert their effects have been limited. Higgins \& Spiegel (2004) have proposed that people tend to pay more attention to messages that are framed more in line with their personal predispositions. Put another way, risk averse people will adhere more to loss framed whereas those who are eager to improve will prefer the gain framed messages. Another possible mechanism points to the congruency of the messages with participants' thoughts and concerns regarding the subject (Updegraff et al., 2007). People who are more concerned about developing hypertension will pay closer attention to messages that mention a relationship between hypertension and the target behavior compared to messages that discuss relationships with the target behavior that are not hypertension related. There has been, however, a call for further research to understand other possible mechanisms (Rothman, \& Updegraff, 2010).

One theory that has been used to investigate the mechanisms through which framed health messages affect physical activity motivation is the Self-Determination Theory (SDT). SDT is interested in one's motives for their behaviors (Deci, \& Ryan, 2000). Within SDT, these motives are divided into two categories: "intrinsic motivation" and "extrinsic motivation". Intrinsic motivation refers to motives that are more internalized in nature; "I want to be physically active because I want to be healthy" would be a good example of intrinsic motivation regarding physical activity participation. In contrast, extrinsic motivation refers to motives based on external cues and social expectations that have been, to a limited degree, internalized. A good example of extrinsic motivation would be "I want to be physically active because I want to be accepted by my peers" (Deci \& Ryan, 2002). It has been proposed that intrinsic motivation can be broken down further into subcategories (often termed "needs") that if satisfied, can lead to optimal growth and functionality. Autonomy is one these categories (DeCharmes, 1968). The role of autonomy within the SDT has also been noted by Deci \& Ryan (2002). They define autonomous motives (often termed "autonomous regulations") as motives that arise from one's own willingness and desire to engage in a particular activity. What is intriguing about autonomous regulation is that it has been shown that people are more satisfied with the outcome of their actions if their reasons for engagement are based on autonomous regulations (Senécal et al., 2000). It has also been demonstrated that exposure to gain framed messages, even for brief periods of time, can lead to the increased formation of autonomous regulations within the target audience (Segar et al., 2012).
The research on SDT theory as an explanatory model for the effects of framed messages has been exemplary. However, no research has been done that directly examines the framing effects of messages regarding physical activity on autonomous regulation. Hence, the purpose of this study is to investigate whether differences in autonomy levels are a consequence of framing. Based on the findings of Latimer et al. (2008) and Segar et al. (2012), we hypothesize that individuals exposed to gainframed messages regarding physical activity will exhibit higher levels of autonomous regulation than those who receive loss-framed physical activity messages.

Some variables (called moderators) have been shown to affect the relationship between framed health messages and their effects on physical activity promotion. One such factor is biological sex (Schwarzer, 2008; Segar et al., 2012). This factor has been measured and accounted for in this study to distinguish the role of increased autonomous regulation from any potential effects of the moderating factor.

\section{2| METHODS}

Study Design: this study used a randomized control design.

Participants: York University undergraduate students ( $\mathrm{N}=107$; 51 females, 56 males), ages 18-30, were recruited through an online portal (Kinesiology Undergraduate Research Experience - KURE). KURE is a research portal that allows undergraduate kinesiology students from York University to enroll in available studies. These 107 students were given bonus marks, in a course that was not taught by any of the researchers in this study, as a token of appreciation for their participation (Figure 1.).

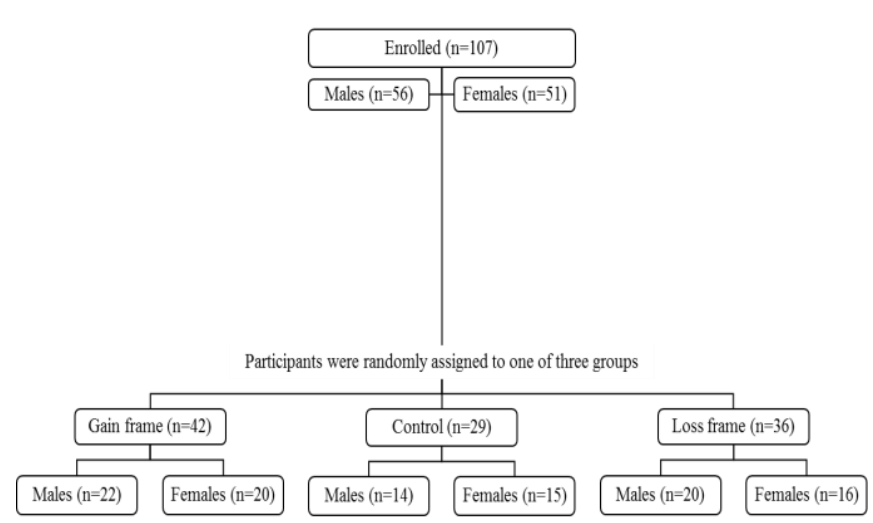

Figure 1. Breakdown of participants involved in the study.

Protocol: An online experiment was conducted using SurveyMonkey. An initial email was sent to all the participants through the KURE system providing them with a link to the study. One to two reminders were sent to participants who were unresponsive to the initial email. Participants were informed 
about the purpose of the study in the beginning of the survey and were asked to indicate their written consent. Upon consenting, the participants were asked to indicate their sex, then randomly assigned to one of three message groups: gainframed, loss-framed and control. These groups were based on the type of framed physical activity message the participant was given. After reading the messages, the participants were asked to fill a previously validated questionnaire assessing autonomous motivation. Questions in the questionnaire were presented in a random order for each participant in order to minimize carryover effects (Tourangeau et al., 1989). Participants were, subsequently, granted their marks. The participants remained anonymous during the course of this survey.

This study was reviewed and approved by the Human Participants Review Sub-Committee, York University's Ethics Review Board and conforms to the standards of the Canadian Tri-Council Research Ethics guidelines (\#E2016 - 335).

Framed physical activity messages: Three different types of messages regarding physical activity were present in this study. The gain-framed and loss-framed messages were taken from a previous study by Bassett-Gunter et al. (2014). Messages were chosen from this particular study because they were designed to be more meaningful to a university student. The control messages, however, had nothing to do with physical activity and were regarding "Secrets of University Success". These messages were taken from York University's website available at; http://lss.info.yorku.ca/resources/10-secrets-of-universitysuccess/. Only the first 5 tips were listed as the control messages. Autonomous regulation: To assess autonomy for physical activity in the participants, adapted items (Segar et al., 2012) were used from the Behavioral Regulation in Exercise Questionnaire (BREQ). Participants were instructed: "The following statements list reasons people often give when asked why they are or would become physically active. Whether you currently are physically active or not, please read each statement carefully and indicate whether or not each statement is or would be true for you personally if you decided to be physically active." Participants responded to four items, using a 7-point scale, from 1 (Not at all true) to 7 (Very true). The value for autonomous regulation was calculated using the following formula: $\frac{\text { (identified regulation }+ \text { intrinsic regulation) }}{2}$, and the value for controlled regulation was calculated using; $\frac{(\text { external regulation }+ \text { introjected regulation })}{2}$, where the

following variables are measured by the following statements: identified regulation, "I truly feel that being physically active is the best thing for me"; intrinsic regulation, "It feels good to be physically active"; external regulation, "I want others to see that I can do it"; introjected regulation, "I would feel bad about myself if I didn't try to be physically active.". Higher scores indicate higher autonomous motivation for physical activity.

Statistical Analysis: A univariate analysis using IBM SPSS (version 24.0) was performed on the data to assess disparities in the different frame condition groups. To that end, frame condition was set as the fixed factor and autonomous regulation as the dependent variable. A second univariate analysis was done to discover any interactions between participants' gender, initial physical activity status and frame condition with regards to autonomous regulation. Upon discovery of an interaction between gender and frame condition, two further univariate analyses (one on each gender) were run to determine the gender which had within-group differences in autonomous regulation. Once it was realized that within-group differences in autonomous regulation existed in the female participants, a one-way ANOVA test was run on the females' autonomous regulation scores setting autonomous regulation as the dependent variable and the frame condition as a factor. Subsequently, a Tukey post hoc test was conducted to detect the nature of these within-group differences.

\section{3 | RESULTS}

Autonomous Regulation: Our initial analysis of the autonomous regulation levels of the three groups (Gain-Frame, Loss-Frame, and control) demonstrated no significant difference in autonomous regulation levels. Figure 2 shows the mean levels of autonomous regulation within the entire study population.

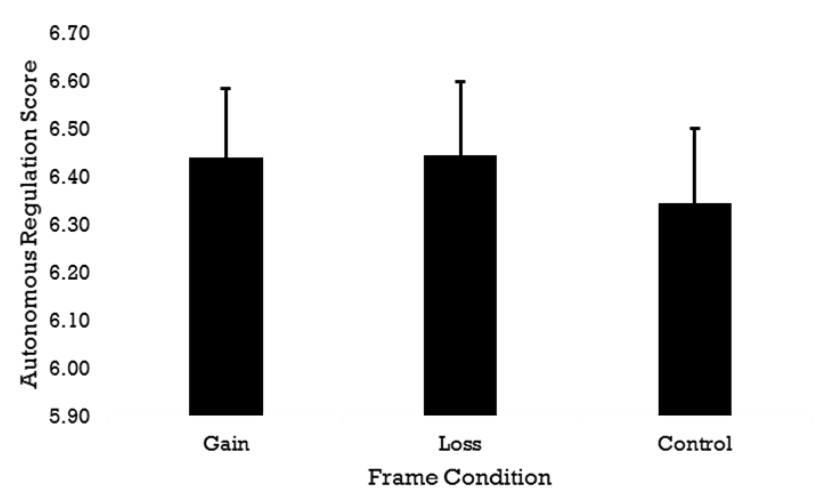

Figure 2. Mean levels of autonomous regulation in the entire sample by frame condition. Error bars show the standard error of the mean.

Upon further investigation however, and through the use of univariate analysis, a significant interaction was shown between participants' gender and frame condition, $\mathrm{F}(2)=4.65$, 
$p=0.012, \eta^{2} p=0.089$. Additional analysis of the different genders demonstrated a significant difference between the mean levels of autonomous regulation in the female participants, $F(2)=3.22, p=0.049$. Similar differences were not observed in the male participants. Figure 3 shows the mean levels of autonomous regulation in the female participants.

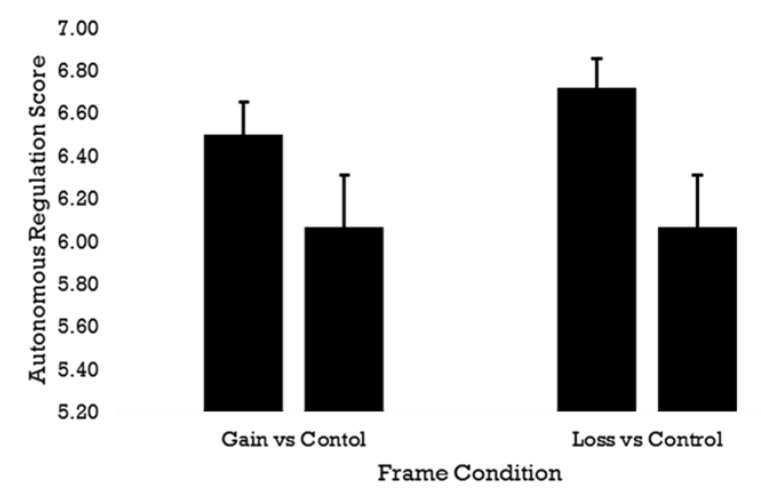

Figure 3. Mean levels of autonomous regulation in female participants by frame condition. Error bars show the standard error of the mean.

A subsequent post hoc analysis showed that the levels of autonomous regulation were significantly higher in the loss frame group when compared to the control group, within the female participants, $p=0.042$. Similar differences were not seen when comparing gain frame to control groups within the female participants.

\section{4 | DISCUSSION}

The findings of this study differed from our hypothesis; we expected the participants who received gain-framed messages to exhibit higher levels of autonomous regulation. This result is contrary to our findings, as in our study, women who were exposed to loss-framed messages exhibited higher levels of autonomy. In a study by Segar et al. (2012), the researchers found that women experience higher levels of autonomous regulation when exposed to gain-framed messages. While a source of intrigue, this contradiction can possibly be explained by further analysis into the different characteristics of the participants. The study done by Segar et al. (2012) recruited participants that were, on average, middle-aged. Participants in our study, however, were all young adults. This age difference can be a potential cause for the conflicting outcomes in our studies. This conclusion is not unreasonable if one considers the research on the age disparity of framing effects. These studies point to the increased influence of loss-framed messages in younger adults (Mikels, \& Reed, 2009), theorizing that younger adults have a propensity to attend to negative information (loss-frame) more so than they do to positive (gain-framed) (Baumeister et al., 2001). Moreover, it has been demonstrated that older adults tend to be more impacted by positive (gainframed) messages as opposed to their negative (loss-framed) counterparts (Carstensen, \& Mikels, 2005; Shamaskin et al., 2010).

Another finding in our study was that framing effects present themselves, significantly, only amongst the female participants. This finding is in opposition to our initial hypothesis. Numerous studies exist that point to the existence of framing effects regardless of gender (Gallagher, \& Updegraff, 2012; Bassett, et al., 2011; Latimer et al., 2010; Jones et al., 2003). The existence of such studies led to our failure to anticipate a gender disparity in framing effects within our participants. It is important to note that while we did not anticipate such differences, we included gender in our data analysis procedures to explore possible interactions, and it appears that all has not been for naught as a significant interaction was revealed. One possible explanation for these inconsistencies between the literature and our research results is that the aforementioned articles demonstrate framing effects with regards to dependent variables other than the one we were experimenting on (autonomy).

When we look at studies that examine the effects of framing on autonomy, we see a similar gender disparity in framing effects with women being the only group benefitting from framing (Segar et al., 2012). It is therefore reasonable to conclude that a gender disparity exists regarding framing effects on autonomy, as it manifests as women being the group on which framing exerts its effects.

\section{Limitations}

This study, of course, is not without its limitations, and must be interpreted with caution. First, our participant sample was relatively small and homogenous; the participants were all undergraduate students from one university. This homogeneity in age and education casts doubts on the generalizability of the results of the study. Second, use of multiple statistical tests on the same data set increases the possibility of type 1 errors occurring (Rothwell, 2005). Third, there were no baseline measurements done on participants' autonomous regulation levels. This lack of a baseline allows an astute observer to wonder whether changes observed in the participants' autonomy was due to framing effects or were preexisting differences. Fourth, there was no assessment of the physical activity behavior as a result of the framing effects under study. While there exists an abundance of studies linking increased autonomy to an increase in physical activity behavior (Hagger et al., 2003; Teixeira et al., 2012), one might still wonder whether an increase in autonomy levels translates 
to an increase in physical activity behavior within our study. Finally, we must note that the findings of this study are based on self-reported variables. Self-reporting of variables may result in a response bias towards more socially acceptable answers, which may challenge the authenticity of the results of this study.

\section{Implications \& Future Directions}

An understanding of how to best frame health messages is of great value to healthcare professionals, governments, and anyone else who is seeking to promote physical activity through the use of messaging. The results of this study can be useful in the shaping of this understating. Furthermore, it is also recommended that future studies focus on how age and sex moderate the effects of framed messages on autonomous motivation for physical activity in broader and more diverse participant pools.

\section{ACKNOWLEDGEMENTS}

The authors thank the School of Kinesiology and Health Sciences at York University for their logistical support during the course of this study. We would also like to thank Dr. Bassett-Gunter for her exceptional support of this project and Dr. Amy E. Latimer-Cheung for her informational support of the study.

\section{REFERENCES}

Bassett-Gunter, R. L., Martin Ginis, K. A., \& Latimer-Cheung, A. E. (2013). Do you want the good news or the bad news? Gain-versus loss-framed messages following health risk information: The effects on leisure time physical activity beliefs and cognitions. Health Psychology, 32(12), 1188. https://doi.org/10.1037/a0030126

Bassett-Gunter, R. L., Latimer-Cheung, A. E., Martin Ginis, K. A., \& Castelhano, M. (2014). I spy with my little eye: cognitive processing of framed physical activity messages. Journal of Health Communication, 196), 676691. https://doi.org/10.1080/10810730.2013.837553

Baumeister, R.F., Bratslavsky, E., Finkenauer, C., \& Vohs, K.D. (2001). Bad is stronger than good. Review of General Psychology, 5, 323-370. https://doi.org/10.1037/10892680.5.4.323

Blanchard, C. M., Stein, K. D., Baker, F., Dent, M. F., Denniston, M. M., Courneya, K. S., \& Nehl, E. (2004). Association between current lifestyle behaviors and health-related quality of life in breast, colorectal, and prostate cancer survivors. Psychology \& Health, 19(1), 1-13. https://doi.org/10.1080/08870440310001606507
Carstensen, L. L., \& Mikels, J. A. (2005). At the intersection of emotion and cognition aging and the positivity effect. Current Directions in Psychological Science, 14(3), 117-121. https://doi.org/10.1111/j.09637214.2005.00348.x

Chandrashekhar, Y., \& Anand, I. S. (1991). Exercise as a coronary protective factor. American Heart Journal, 1226), 1723-1739. https://doi.org/10.1016/00028703(91)90290-X

Colley, R. C., Garriguet, D., Janssen, I., Craig, C. L., Clarke, J., \& Tremblay, M. S. (2011). Physical activity of Canadian adults: accelerometer results from the 2007 to 2009 Canadian Health Measures Survey. Health Reports, 22(1), 7. Retrieved from https://www.researchgate.net/profile/Ian_Janssen/publi cation/284685407_Physical_activity_of_Canadian_adu lts_accelerometer_results_from_the_2007_to_2009_C anadian_Health_Measures_Survey_Health_ReportsSta tistics_Canada_Canadian_Centre_For_Health_Inform ationRapports_Sur_La_S/links/568bb7ba08aele63flfdd 639/Physical-activity-of-Canadian-adults-

accelerometer-results-from-the-2007-to-2009-CanadianHealth-Measures-Survey-Health-Reports-StatisticsCanada-Canadian-Centre-For-HealthInformationRapports-Sur-L.pdf

DeCharmes, R. (1968). Personal causation. New York: Academic. https://doi.org/10.1111/j.15591816.1972.tb01266.x

Deci, E. L. (86). 8: Ryan, RM (1985). Intrinsic motivation and self-determination in human behavior. New York and London: Plenum.

Deci, E. L., \& Ryan, R. M. (2000). The" what" and" why" of goal pursuits: Human needs and the self-determination of behavior. Psychological Inquiry, 11(4), 227-268. https://doi.org/10.1207/S15327965PLI1104_01

Deci, E. L., \& Ryan, R. M. (2002). Handbook of Selfdetermination Research. University Rochester Press.

Derby, C. A., Mohr, B. A., Goldstein, I., Feldman, H. A., Johannes, C. B., \& McKinlay, J. B. (2000). Modifiable risk factors and erectile dysfunction: can lifestyle changes modify risk?. Urology, 56(2), 302-306. https://doi.org/10.1016/S0090-4295(00)00614-2

Gallagher, K. M., \& Updegraff, J. A. (2012). Health message framing effects on attitudes, intentions, and behavior: a meta-analytic review. Annals of Behavioral Medicine, 43(1), 101-116. https://doi.org/10.1007/s12160-012-9446-6

Hagger, M. S., Chatzisarantis, N. L., Culverhouse, T., \& Biddle, S. J. (2003). The processes by which perceived autonomy support in physical education promotes leisure-time physical activity intentions and behavior: a trans- 
contextual model. Journal of Educational Psychology, 95(4), 784. https://doi.org/10.1037/0022-0663.95.4.784

He, X. Z., \& Baker, D. W. (2004). Body mass index, physical activity, and the risk of decline in overall health and physical functioning in late middle age. American Journal of Public Health, 94(9), 1567-1573.

https://doi.org/10.2105/AJPH.94.9.1567

Higgins, E. T., \& Spiegel, S. (2004). Promotion and prevention strategies for self-regulation: A motivated cognition perspective. In R. F. Baumeister \& K. D. Vohs (Eds.), Handbook of self-regulation: Research, theory and applications (pp. 171-187). New York: Guilford Press. Retrieved from https://dl.uswr.ac.ir/bitstream/Hannan/132111/1/Roy_F ._Baumeister\%2C_Kathleen_D._Vohs_Handbook_of_S elf-

Regulation_Research\%2C_Theory\%2C_and_Applicatio ns__2004.pdf\#page=189

Jones, L. W., Sinclair, R. C., \& Courneya, K. S. (2003). The effects of source credibility and message framing on exercise intentions, behaviors, and attitudes: An integration of the elaboration likelihood model and prospect theory. Journal of Applied Social Psychology, 33(1), 179-196. https://doi.org/10.1111/j.15591816.2003.tb02078.x

Latimer, A. E., Rench, T. A., Rivers, S. E., Katulak, N. A., Materese, S. A., Cadmus, L., Hicks, A., Hodorowski, J. K. and Salovey, P. (2008), Promoting participation in physical activity using framed messages: An application of prospect theory. British Journal of Health Psychology, 13. 659-681. https://doi.org/10.1348/135910707X246186

Latimer, A. E., Brawley, L. R., \& Bassett, R. L. (2010). A systematic review of three approaches for constructing physical activity messages: What messages work and what improvements are needed? International Journal of Behavioral Nutrition and Physical Activity, 71), 1. https://doi.org/10.1186/14795868-7-36

Levin, I. P., Schneider, S. L., \& Gaeth, G. J. (1998). All frames are not created equal: a typology and critical analysis of framing effects. Organizational Behavior and Human Decision Processes, 76(2), 149-188. https://doi.org/10.1006/obhd.1998.2804

Lin, S. Y., Davey, R. C., \& Cochrane, T. (2004). Community rehabilitation for older adults with osteoarthritis of the lower limb: a controlled clinical trial. Clinical Rehabilitation, 18(1), 92-101. https://doi.org/10.1191/0269215504cr706oa
Mikels, J. A., \& Reed, A. E. (2009). Monetary losses do not loom large in later life: age differences in the framing effect. The Journals of Gerontology Series B: Psychological Sciences and Social Sciences, 64(4), 457460. https://doi.org/10.1093/geronb/gbp043

Morris, C. K., \& Froelicher, V. F. (1991). Cardiovascular benefits of physical activity. Herz, 16(4), 222-236.

Paffenbarger, R. S., Wing, A. L., Hyde, R. T., \& Jung, D. L. (1983). Physical activity and incidence of hypertension in college alumni. American Journal of Epidemiology, 1173), 245-257. https://doi.org/10.1093/oxfordjournals.aje.al13537

Paffenbarger Jr, R. S., Hyde, R., Wing, A. L., \& Hsieh, C. C. (1986). Physical activity, all-cause mortality, and longevity of college alumni. New England Journal of Medicine, 314(10), 605-613. https://doi.org/10.1056/NEJM198603063141003

Penedo, F. J., Schneiderman, N., Dahn, J. R., \& Gonzalez, J. S. (2004). Physical activity interventions in the elderly: cancer and comorbidity. Cancer Investigation, 22(1), 5167. https://doi.org/10.1081/CNV-120027580

Ross, C. E., \& Hayes, D. (1988). Exercise and psychologic wellbeing in the community. American Journal of Epidemiology, 1274), 762-771. https://doi.org/10.1093/oxfordjournals.aje.al14857

Rothwell, P. M. (2005). Subgroup analysis in randomised controlled trials: importance, indications, and interpretation. The Lancet, 365(9454), 176-186. https://doi.org/10.1016/S0140-6736(05)17709-5

Segar, M. L., Updegraff, J. A., Zikmund-Fisher, B. J., \& Richardson, C. R. (2012). Physical activity advertisements that feature daily well-being improve autonomy and body image in overweight women but not men. Journal of Obesity, 2012. https://doi.org/10.1155/2012/354721

Senécal, C., Nouwen, A., \& White, D. (2000). Motivation and dietary self-care in adults with diabetes: are self-efficacy and autonomous self-regulation complementary or competing constructs?. Health Psychology, 195), 452. https://doi.org/10.1037/0278-6133.19.5.452

Shamaskin, A. M., Mikels, J. A., \& Reed, A. E. (2010). Getting the message across: age differences in the positive and negative framing of health care messages. Psychology and Aging, 25(3), 746. https://doi.org/10.1037/a0018431

Smith, S. C., Blair, S. N., Criqui, M. H., Fletcher, G. F., Fuster, V., Gersh, B. J., ... \& Hill, M. N. (1995). Preventing heart attack and death in patients with coronary disease. Journal of the American College of Cardiology, 26(1), 292-292. Retrieved from 
https://www.jacc.org/doi/pdf/10.1016/0735-

1097\%2895\%2990846-G

Stephens, T. (1988). Physical activity and mental health in the United States and Canada: evidence from four population surveys. Preventive Medicine, 171), 35-47. https://doi.org/10.1016/0091-7435(88)90070-9

Schwarzer, R. (2008). Modeling Health Behavior Change: How to predict and modify the adoption and maintenance of health behaviors. Applied Psychology, 571), 1-29. https://doi.org/10.1111/j.1464-0597.2007.00325.x

Teixeira, P. J., Carraça, E. V., Markland, D., Silva, M. N., \& Ryan, R. M. (2012). Exercise, physical activity, and selfdetermination theory: a systematic review. International Journal of Behavioral Nutrition and Physical Activity, $9(1), 78$.

https://doi.org/10.1186/1479-5868-9-78

Tiggemann, M. (2004). Body image across the adult life span: Stability and change. Body Image, 1(1), 29-41. https://doi.org/10.1016/S1740-1445(03)00002-0
Tremblay, M. S., Warburton, D. E., Janssen, I., Paterson, D. H., Latimer, A. E., Rhodes, R. E., ... \& Murumets, K. (2011). New Canadian physical activity guidelines. Applied Physiology, Nutrition, and Metabolism, 36(1), 36-46. https://doi.org/10.1139/H11-009

Tourangeau, R., Rasinski, K. A., Bradburn, N., \& D'ANDRADE, R. O. Y. (1989). Carryover effects in attitude surveys. Public Opinion Quarterly, 53(4), 495-524. https://doi.org/10.1086/269169

Updegraff, J.A., Sherman, D.K., Luyster, F.S., \& Mann, T.L. (2007). The effects of message quality and congruency on perceptions of tailored health communications. Journal of Experimental Social Psychology, 43, 249257. https://doi.org/10.1016/j.jesp.2006.01.007

Uusitupa, M., Louheranta, A., Lindström, J., Valle, T., Sundvall, J., Eriksson, J. and Tuomilehto, J. (2000) The Finnish diabetes prevention study. British Journal of Nutrition, 83(S1), pp. S137-S142. https://doi.org/10.1017/S000711450000107

How to cite this article: Azmi, A., \& Cruz, C. B. (2020). A tale of two frames: a study on the effects of framed health messages on autonomous motivation for physical activity. Eureka University of Alberta Science Undergraduate Research Journal., 5(1), $22-28$. https://doi.org/ 10.29173/eureka28753 


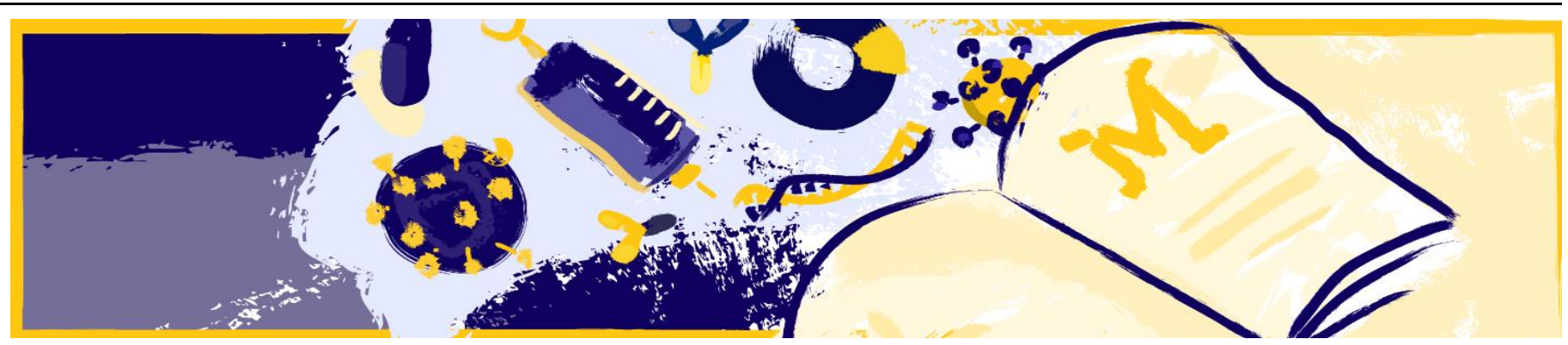

The talk of the town (or at least the University of Alberta) has been your Nobel Prize. How does it feel to finally be recognized for that work?

It feels nice. Big honor, of course, to get the Nobel. We did the work in the 80 s - that was 30 years ago - it has been a long time but it is nice that I got it while I was working here because it helps the U of A, so I'm pleased about that.

\section{Dr. Michael Houghton was honored with the Nobel Prize in Physiology and Medicine this fall. Eureka asked \\ Dr. Houghton about his career, advice to his undergraduate self, and publication experiences.}

\section{Why did you pick the $U$ of $A$ ? What drew you here, and why did you stay?}

I think there were 3 reasons: one is that I wanted to work with Lorne Tyrell. I knew him from the viral hepatitis field for many years, I liked him, and he had been doing good work in Hep B and Hep C. Wherever I went I wanted to have someone I knew and trusted, so Lorne has been that person. He's been a wonderful collaborator and mentor. Number two, I wanted funding and I got that with the Canada Excellence in Research Chair. I won that grant and it's 10 million dollars - so it's a big grant. And number three, I wanted to go to a place that had a good reputation. The University of Alberta, in the field of hepatitis through Lorne and through its virologists, was well known and well respected.

What did you expect a career in academia would be like back in your undergraduate days, before you started research?

Well, my career has been a little different from most scientists. After my undergraduate degree in England, I went straight into the research wing of a large pharmaceutical company. I actually did my PhD working in the company, but I was registered as a PhD student at the University of London in England. Thereafter, I stayed in the private sector working for research labs within pharmaceutical companies in England and then in the US, so a bit unusual. When I joined the University of Alberta back in 2010, that was, in a sense, my re-entry into academia. While I've always been a researcher, the two places (the private sector and the universities) are really quite different cultures. But I think what I've been doing in Alberta is very similar to what I've been doing in industry, which is taking our current scientific knowledge and technology and seeing if you can use it to be of benefit to patients and their clinicians.

I'm very much a translational scientist. In my department, Medical Microbiology and Immunology at the U of A, it's mostly basic science trying to find out how the cell works, how the virus works, bacteria, and so forth, hoping that some of that can be applied in the future. I take information that's available now, and I think we can apply it to important diseases. For example, working with one of our distinguished professors, Jack Jhamandas, as a neurologist he sees a lot of Alzheimer's patients. We're working with him on a new approach to developing Alzheimer's drugs and we're getting some very interesting results in his cell systems as well as animal models. In a way, working in the Li Ka Shing Applied Virology Institute is very similar to my 40 years in the private sector in the UK and the US. 
As a researcher, what is the publication and peer review process like from within industry? Does it change the way that you publish papers, and do you find that different now that you're in academia "officially"?

No, it doesn't really. I have published around 300 papers, and most of that from industrial research labs. Even in the applied virology institute, where I've worked for 10 years, that's kind of an industrial setting so the only difference really is before you send your paper in. If it's important enough and could potentially translate to human health care, then you file a patent, and filing a patent usually takes 1-2 months. Once you file the patent, your invention is covered for clinical translation and commercialization and then you publish. The whole process of clinical development involving 3 testing phases costs typically around C\$ 150 million. You cannot get partners to do that unless you have patent protection.

In industry, the best companies have very good researchers. They have to, otherwise they will fail. You don't just take current knowledge and apply it to disease, you have to be doing your own research. I worked at Chiron, this company in the States, for 25 years where we discovered the hepatitis C virus; I worked with really good scientists many of whom were at senior Professor levels of excellence.

From the angle of academic publishing, a lot of the time it's "publish or perish", so it becomes very individualistic. Do you think you retain that sense of individualism and pressure to publish from within industry?

No, there isn't that kind of publishing pressure in industry. The pressure is to make medical innovations and from those, commercial products. Industry essentially is funded by investors, stockholders - they want you to make money (that's why they bought your shares), so they don't care much about what you're publishing as long as you perform research that eventually leads to a medical innovation.

That said, as research scientists in industry, we all still like to publish just like academic scientists to share our progress, which is how scientific fields progress.

\section{Do you remember your first publication experience?}

Oh yeah! The characterization of the RNA polymerase from chicken oviducts. It wasn't a particularly interesting paper, but I was very proud of that first paper.

Industry is something that a lot of students here don't consider as something they could immediately transition into, so your perspective starting in industry and applying that to academia is really valuable.

I'm talking to you from my US house just outside of San Francisco, and there are a lot of world-class research universities in the Bay area. Not only for undergraduates, but for postgraduates and postdoctoral fellows and faculty - top-class Professors are heavily engaged with the pharmaceutical and Biotech industry here. In many cases, the professors start their own companies or consult for other companies. In Alberta, that culture is not as prevalent, but it is changing. Once Alberta has 1 or 2 major successes in medical innovation and Biotech commercialisation, that will catalyse a key industry just like it did in the Bay Area of California, San Diego and Boston. Alberta badly needs an alternate industry and with its excellent Universities and secondaries, it can definitely foster a global Biotech presence.

This is interesting - they're very separate here and it's sometimes considered a sellout to go to industry. And yet that's not necessarily the case if you go to a place that's saturated with biotech.

That's not the case particularly in the US, UK and EU. It's not seen as a sellout but as highly desirable. If you want to be a professor in biomedicine and you want to get ahead, it's almost obligatory that you work with industry in some capacity. 50 years ago in the UK (which is where I was born and trained), they had an ivory tower mentality but that all changed in the 1980's with the emergence of monoclonal antibody technology from Cambridge University. That spawned a huge Biotech industry in Cambridge and across the rest of the UK and world. 
It's an interesting point because basic scientists are often lowly funded. If there was just a little bit more communication and integration, then I could see that as being something that would take us far.

It's a very good topic - our Li Ka Shing Applied Virology Institute has been generously funded by the government of Alberta who have seen our potential in helping to advance the Biotech industry in Alberta which badly needs a new industry sector. As a result, we have a lot of collaborating principal investigators. For example, a program designed to develop a vaccine against Group A Streptococcus is being led by an adjunct professor in MMI (Dr. Michael Good). He's a global leader in that field and we're happy to sponsor some of his work. Hopefully, we'll have a clinical trial starting in Edmonton in 2021 to test his novel vaccine approach. We are also working with Professor Jack Tuszynski and Professor Khaled Barakat from the UofA as well as Professor Sergei Noskov (UCalgary) and Dr Kamlesh Sahu in our Institute who are all experts in Computation-Assisted-Drug-Discovery (CADD). This is fast becoming the new way to discover drugs including those that abrogate protein: protein interactions that have been very difficult to target in the past. We also work closely with UofA Distinguished Professor Jack Jhamandas on developing novel drugs for Alzheimer's disease and are seeing some exciting progress arising from the CADD science of Dr Kamlesh Sahu. Other exciting work is being done by Dr James Nieman and synthetic chemists in our institute who are developing potent new antivirals against human cytomegalovirus.

\section{"Why do you do research in biomedicine? It's not really to further the hobbies of scientists, it's to make health better for the community."}

If we're going to have talent retention and develop Alberta to be a place that people want to come to do biomedical research, then it sounds like something has to change.

I think funding has to increase to better enable our excellent scientists throughout Alberta and they in turn need to focus more on biomedical innovation in addition to basic research. I think Covid really is a wakeup call - it should teach the governments of the world to increase funding for infectious disease research since humans are under the constant threat of emerging viruses, parasites, and antibiotic-resistant bacteria.

Unfortunately, the current academic system is very much geared around publishing. Therefore, the research topic has to be very accessible to students and trainees; what that means is that you, as a trainee, cannot work on very difficult and uncharacterised areas of unmet medical need. And I think that's a pity. I do think students and profs need to spend a bit more time thinking about major diseases. You can't do it $100 \%$ of the time. If you had spent your $\mathrm{PhD}$ and your postdoc working on trying to find the Hep C virus for 7 years, you wouldn't get many papers along the way and then your career would have suffered. I think there needs to be a better balance in the future and perhaps this can be facilitated by changes in the funding agencies who could fund more grants in difficult medical areas, unleashing young minds on the problems.

There's actually a real niche for this that can be filled- we often have these pillars that don't communicate. Actively reaching out and bridging those gaps is what's missing in translatability - you're right that we live in these little silos and it's industry, basic science, or clinic - they don't communicate.

\section{"I'm still as motivated as much as I was 50 years ago, just older and more fatigued, but hopefully wiser."}

You're dead right, everyone tends to be in their own silo. We need clinicians working actively with basic and translational scientists taking up challenges in unsolved diseases (there are so many) and being facilitated by new incentives from the funding agencies.

I think in the United States and UK, the funding agencies have become a lot more translational in intent. In other words, they want to see even the basic science grants having more of a potential medical and societal output, which I

think is good. It's true that if you look at the Nobels awarded this year for the Crispr- Cas9 system, there was no medical ambition originally in this research. It was curiosity - and basic research - driven but will enable many major medical breakthroughs, so basic research must continue. But overall, a better balance of basic and translational science would better serve society's needs, I feel. 
I think we need to foster an interdisciplinary approach to disease in our young researchers: To think not just about your own research problems, but how other people in different disciplines can contribute to it and how you can interest other people in it.

We are part of an interdisciplinary NIH grant on the Hep C vaccine, and we just got news of obtaining a good review score that is in the fundable range. In the US, the NIH have a program where they're going to fund 40 million dollars of research on Hep C vaccines. And they're going to give four 10-million-dollar grants to different interdisciplinary teams from multiple sites. There's a reasonable chance we'll be part of one of those grants. I have applied for similar grants to Canadian funding agencies without success, which is disappointing since we are one of the global leaders in this particular field.

What do you think CIHR and Canadian granting agencies as a whole could learn from what you value about the American system?

What you hear from CIHR is 'We spend a lot of money. We spend a billion dollars on research every year'. And they do. But only one of those pillars is on biomedical research - there should be more emphasis on basic and translational biomedical research from CIHR in my opinion and as Covid19 has taught us, more funding should be applied to infectious disease research. Canada has a fine cadre of biomedical scientists limited only by

“Anticipate what's going to be big in ten years time and plot your career around that." funding.

I'd like to take you back in time to your beginnings as a scientist. Was your motivation in your early career the same as today, or have your drivers to do science changed?

My attitude hasn't changed in the 50 years I've been doing medical research. I'm still very motivated to contribute to medical research and make innovations to help patients. I'm still as motivated as much as I was 50 years ago, just a little older and more fatigued, but hopefully wiser.

It seems you were very convicted in your career early on, especially if your motivations haven't changed at all since the beginning. Was there a driving moment for you that made you want to approach science the way that you have?

Whenever I was coming downstairs from chemistry lessons at high school, I would always stop and look into the biology lab to see what they were doing. So, I had this innate interest in biology - in the processes of life. Later, thinking about what I wanted to do when I was going to study at university, I spent a week in the local library investigating various careers. They had a small room of career listings from A to Z; I spent a week just going through systematically reading all of the books in that room. When I got to M - Microbiology - I read about Louis Pasteur and I thought 'Wow, this is fantastic. This is what I want to do'. That was a very important moment. Until that point, I had studied physics, chemistry, and math - then I decided to study biology at University. Pasteur's life and his work were strong motivators for me, and I took a little bit of an unusual route joining industry so quickly. And yeah, I still feel the same way. There are so many diseases that we know so little about, let alone have therapies for, and I don't think that's right.

\section{“When I got to M - Microbiology - I read about Louis Pasteur and I thought 'Wow, this is fantastic. This is what I want to do'."}

I think we've got enough smart people in the world and enough money to do better against disease. I mean Multiple Sclerosis why don't we know more about MS? ALS? Inflammatory bowel disease? Alzheimer's? Et cetera, et cetera. We're smart enough as a scientific community to be able to do better. Covid-19 vaccinology is a great example of how novel creative science can really excel, but we should be doing better in other areas of disease I feel. 
Do you have any advice for somebody who's first starting to think about what kind of career in science they're interested in?

Well, one of my mentors many years ago - a great Prof (Richard Palmiter) at the University of Washington in Seattle - taught me a couple of things as a student. He said that you've first got to ask the right questions.

'What question are you trying to answer, Mike, in science?'

I said 'Well, I'm trying to extract chromatin and study gene regulation in vitro'.

'But what fundamental question do you have, Mike?'

Sounds obvious, doesn't it? But when we're young, as trainees, we don't always do that. We're just following maybe what our professor is guiding us to do. Each of us has got to ask, 'What are the questions we want to address in our research and lives?'. The second piece of advice I got from Richard was: think about what field is going to be big in ten years time. Don't join a field that's already big now. Anticipate what's going to be big in ten years time and plot your career around that. If we all jumped into Covid vaccine research right now, it's very competitive and a lot has already been done. Try to figure out what's going to be big in ten years. Much of immunology and neurology fields are still black boxes. We still don't understand a lot about these disciplines, but we will for sure in 10-20 years.

People ask me: Why did you decide to hunt for the hepatitis C virus? And I think it was partly because of that advice Richard Palmiter gave me. I thought 'It's very difficult, a lot of people have been working on it already but without success. We don't really have the techniques available to solve it now but, maybe in the future, we can figure out a way. And then it really will be big for medicine'. Maybe that was part of it.

You said something interesting during your conversation with Dr. Brenda Hemmelgarn for the Faculty of Medicine and Dentistry about the cross-referencing of techniques between disciplines

I didn't do as much literature research as I should have done. I've always not been good in that aspect, throughout my young career. But I would advise trainees to dedicate a morning every week reading Science and Nature and Cell, because that's really where the big inventions are published for the first time. It's so important. Technology determines what we can accomplish scientifically. It's an obvious statement but many of us don't keep up with the technologies which are growing exponentially and are hard to keep up abreast of, but it is essential we do so.

\section{As a senior Nobel Laureate, what advice would you give yourself as an undergraduate student?}

To me, the most important thing to have as a researcher is passion for what you're doing. You've got to have a passion. You've really got to want to do it. And if you don't, find something else because it's a pretty hard life without that passion. You're scrounging around for money and grants and all that. Find your passion - it could be anything. You might want to be a ballet dancer or forester. Find out what it is that drives you, what motivates you, because if you find your passion and you work on it, you'll enjoy your life very much and you'll have a great chance of success also.

\section{“Technology determines what we can accomplish scientifically."}

And maybe, don't be too ambitious. I was never that ambitious. All I wanted to do when I started after university was to make a contribution to medical research. It didn't have to be a big contribution - as long as it's a contribution and it doesn't matter if you actually even fail to make a contribution. As long as you're trying to make a contribution, that's the important thing. 


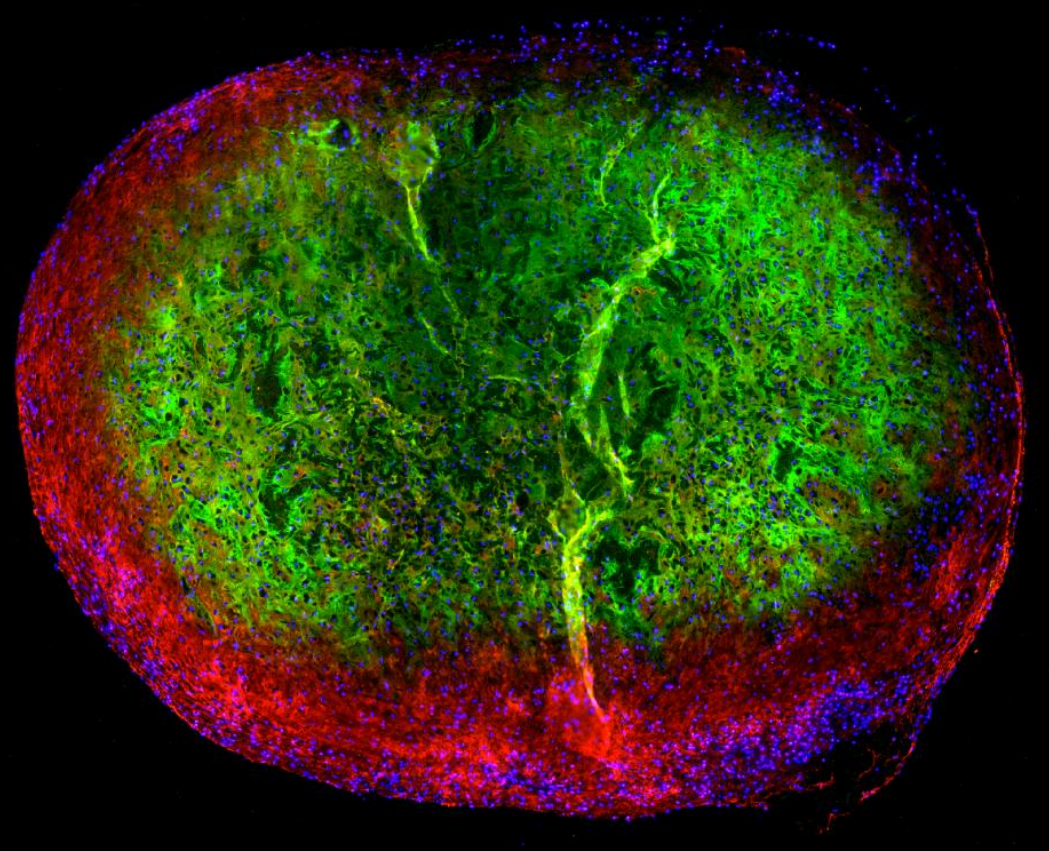

eureka 